\title{
An in vitro selection strategy identifying naked DNA that localizes to cell nuclei
}

Supporting Material

John Smestad ${ }^{1,2, \#, ~ B r a n d o n ~ W i l b a n k s ~}{ }^{2, \#}$ and Louis J. Maher III',*

${ }^{1}$ Medical Scientist Training Program, Mayo Clinic College of Medicine and Science, Rochester, MN, 55905, USA

2 Department of Biochemistry and Molecular Biology, Mayo Clinic College of Medicine and Science, Rochester, MN, 55905, USA

\# These authors contributed equally.

* To whom correspondence should be addressed.

Tel: +1 507-284-9041

Fax: +1 507-284-2053

Email:maher@mayo.edu

\section{Table of Contents}

\section{Materials and Methods}

1. Construction of naïve DNA library for in vitro selection of karyophilic DNA aptamers

2. Preparation of DNA-ligase sensitive library constructs

3. Pilot ligation, bead capture, and PCR amplification

4. Karyophilic selection in cell culture

5. Aptamer cloning and sequencing

6. Synthetic oligonucleotides for characterization studies

7. Aptamer thermal melting studies

8. Nuclease susceptibility characterization

9. Chemical reactivity analysis of aptamer native structures

10. Mung Bean nuclease profiling of aptamer native structures

11. Proteomic analysis of aptamer-interacting partners

12. Cellular fractionation and qPCR detection of aptamer localization

13. Knockdown of cell uptake pathways

2. Supporting Figures

3. Supporting Table

4. Supporting References 


\subsection{Materials and Methods}

\subsection{Construction of naïve DNA library for in vitro selection of karyophilic DNA aptamers}

All oligonucleotides were synthesized by Integrated DNA Technologies. Abbreviations in oligonucleotide sequences "5Phos", " $+\mathrm{N}$ ", "3BioTEG", and "iSp18" correspond to 5" phosphorylation, LNA modified base, 3' biotin-triethylene glycol, and internal 18 atom spacer, respectively. Oligonucleotides LJM-5303 (/5Phos/GTGCTA+CG+CC+A/3BioTEG/), LJM-5305

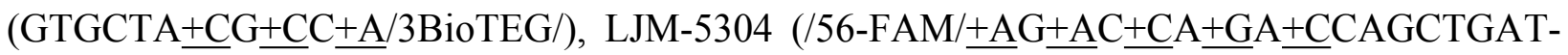
$\left.\mathrm{AC}_{2} \mathrm{AGTCGTG}\right)$, and LJM-5318 (A $\left.20 / \mathrm{iSp} 18 / / \mathrm{iSp} 18 / \mathrm{TCAG}_{2} \mathrm{AG}_{2} \mathrm{AGCAG}_{2} \mathrm{TG}_{2} \mathrm{CT}_{2} \mathrm{G}_{2} \mathrm{CGT}\right)$ were reconstituted in water to $5 \mu \mathrm{M}$ concentration. LJM-5321 $\left(\mathrm{GAC}_{2} \mathrm{AGCTGATAC}_{2} \mathrm{AGTC}\right.$ $\mathrm{GTGN}_{55} \mathrm{TACGC}_{2} \mathrm{~A}_{2} \mathrm{GC}_{2} \mathrm{AC}_{2} \mathrm{TGCTC}_{2} \mathrm{TC}_{2}$ ) was reconstituted to $1 \mu \mathrm{M}$ concentration. The naïve karyophilic SELEX library was created starting with PCR using the following reagent volumes: $200 \mu \mathrm{L}$ 10x Taq pol buffer, $200 \mu \mathrm{L}$ 10x BSA, $160 \mu \mathrm{L} 50$ mM MgCl $2,160 \mu \mathrm{L} 2.5$ mM dNTPs, 200 $\mu \mathrm{L} 5 \mu \mathrm{M}$ forward primer LJM-5304 (500 pmol), $200 \mu \mathrm{L} 5 \mu \mathrm{M}$ reverse primer LJM-5318 (500 pmol), $760 \mu \mathrm{L}$ water, $80 \mu \mathrm{L}$ DNA template (LJM-5321; $1 \mu \mathrm{M}$ stock; 80 pmol), and $40 \mu \mathrm{L}$ Taq polymerase (Invitrogen, cat \# 10342020). Reagents were mixed, aliquoted in $100 \mu \mathrm{L}$ volumes into PCR tubes, and subjected to thermal cycling using the following protocol: $6 \times\left(60 \mathrm{~s}\right.$ at $94^{\circ} \mathrm{C}, 75 \mathrm{~s}$ at $55^{\circ} \mathrm{C}, 120 \mathrm{~s}$ at $72^{\circ} \mathrm{C}$ ). Following amplification, all aliquots were recombined into a single $5 \mathrm{~mL}$ centrifuge tube. $3 \mathrm{M} \mathrm{NaOAc}(0.1$ volume) was added and mixed. Nucleic acids were precipitated by the addition of 1 volume of isopropanol, mixing, incubation on dry ice for $10 \mathrm{~min}$, and then centrifugation at 4,500 $\times \mathrm{g}$ for $15 \mathrm{~min}$. The resulting pellet was washed with $750 \mu \mathrm{L}$ cold $70 \%$ ethanol followed by centrifugation for $10 \mathrm{~min}$. The pellet was then dried in air, resuspended in 40 $\mu \mathrm{L}$ water, combined with $160 \mu \mathrm{L}$ deionized formamide, heated to $90{ }^{\circ} \mathrm{C}$ for $5 \mathrm{~min}$, and loaded onto a 10\% denaturing polyacrylamide gel (7.5 M urea; 19:1 bis:acrylamide) and subjected to electrophoresis for $3 \mathrm{~h}$ at $600 \mathrm{~V}(26 \mathrm{~V} / \mathrm{cm})$. DNA bands were visualized by UV shadowing over a TLC plate with a fluorescent indicator. The higher mobility DNA band containing the purified fluorescent single stranded library was excised using a clean razor blade. The band was then cleaved into small (1-2 mm) cubes and eluted overnight at $37^{\circ} \mathrm{C}$ in $400 \mu \mathrm{L} 2 \times$ PK buffer $(100 \mathrm{mM}$ Tris-Cl (pH 7.5), $200 \mathrm{mM} \mathrm{NaCl}, 2 \mathrm{mM}$ EDTA, 1\% SDS) with gentle agitation. The supernatant 
was then transferred and extracted with an equal volume of (1:1) phenol:chloroform. The upper aqueous phase was then precipitated from ethanol. Samples were then warmed to room temperature and subjected to centrifugation at $17,000 \times \mathrm{g}$ for $15 \mathrm{~min}$. The resulting pellet was washed with $500 \mu \mathrm{L}$ of cold $70 \%$ ethanol, air dried, and resuspended in $200 \mu \mathrm{L}$ water. The concentration of the library was estimated using a molar extinction coefficient of 1,022,500 (M$\mathrm{cm})^{-1}$. The library was then stored protected from light at $4{ }^{\circ} \mathrm{C}$.

\subsection{Preparation of DNA-ligase sensitive library constructs}

To generate DNA ligase-sensitive constructs, equal moles of library, splint primer oligonucleotide LJM-5320 ( $\left.\mathrm{TG}_{2} \mathrm{CGTAGCACTCAG} \mathrm{AG}_{2} \mathrm{AGCAG}_{2} \mathrm{TG}_{2} \mathrm{CT}_{2} \mathrm{G} / 3 \operatorname{InvdT} /\right)$, and LJM-5303 (/5Phos/GTGCTA $+\mathrm{CG}+\mathrm{CC}+\underline{\mathrm{A}} / 3 \mathrm{BioTEG} /)$ were assembled a $100 \mathrm{nM}$ each in $5 \mathrm{mM}$ sodium phosphate buffer, $\mathrm{pH} 6.5$, containing $50 \mathrm{mM} \mathrm{NaCl}$. Solutions were mixed, heated to $90{ }^{\circ} \mathrm{C}$ for $5 \mathrm{~min}$, and then allowed to cool to room temperature. Constructs were then used immediately in experiments.

\subsection{Pilot ligation, bead capture, and PCR amplification}

DNA ligase-sensitive constructs were generated by combining 5 pmol each of library, splint oligonucleotide LJM-5320, and LJM-5303 at $100 \mathrm{nM}$ each in 1× New England Biolabs (NEB) T4 DNA ligase buffer containing adenosine triphosphate (NEB B0202S). Solutions were heated to $90{ }^{\circ} \mathrm{C}$ for $5 \mathrm{~min}$, and then allowed to cool $16{ }^{\circ} \mathrm{C}$. T4 DNA ligase ( $1 \mu \mathrm{L}$; NEB M0202S) was then added to each tube. Tubes were mixed and then incubated at $16{ }^{\circ} \mathrm{C}$ for $30 \mathrm{~min}$. DNA ligase was heat inactivated by heating to $65{ }^{\circ} \mathrm{C}$ for $10 \mathrm{~min}$. To assess DNA ligase activity of conditioned cell culture medium and whole cell extract, library, splint primer oligonucleotide, and ligation primer were prepared and annealed as described above, but in phosphate-buffered saline (PBS). Conditioned medium or whole cell extract $(25 \mu \mathrm{L})$ were then added and samples were incubated at $33{ }^{\circ} \mathrm{C}$ for $30 \mathrm{~min}$. Biotinylated DNA in all samples was then captured on $20 \mu \mathrm{L}$ of M270 streptavidin Dynabeads (Invitrogen 65305), washed $3 \times$ with binding and wash buffer (5 mM Tris-HCl, $\mathrm{pH} 7.5,0.5 \mathrm{M}$ EDTA, $1 \mathrm{M} \mathrm{NaCl})$ once with sodium citrate buffer $(0.15 \mathrm{M} \mathrm{NaCl}, 0.015$ $\mathrm{M}$ sodium citrate, $\mathrm{pH}$ 7.0), using a magnet to retain the beads between washes. Residual adherent non-biotinylated DNA strands were then denatured and released by incubating beads in $0.15 \mathrm{~N}$ $\mathrm{NaOH}$ at room temperature for $10 \mathrm{~min}$, and scrupulously removed from the beads. Beads were 
then washed once more with $0.15 \mathrm{~N} \mathrm{NaOH}$, once with binding and wash buffer, and once with $1 \times$ TE buffer (10 mM Tris-HCl, pH 8, 1 mM EDTA). Beads were then resuspended in $50 \mu \mathrm{L}$ of TE buffer. 1.5 $\mu \mathrm{L}$ bead suspension was added to $28.5 \mu \mathrm{L}$ of PerfeCTa FastMix (Quanta Bio 95118250) containing $500 \mathrm{nM}$ primers LJM-5304, and LJM-5318. Samples were transferred to an iCycler qPCR instrument and subjected to thermal cycling using a protocol of $40 \times\left(15 \mathrm{sec}\right.$ at $95^{\circ} \mathrm{C}$; $45 \mathrm{sec}$ at $70^{\circ} \mathrm{C}$ ), collecting SYBR Green fluorescence measurements during the anneal/extension step of each cycle. Raw fluorescence data were then exported and analyzed in R.

\subsection{Karyophilic aptamer selection in cell culture}

Naïve karyophilic DNA library was assembled with the ligase sensor-domain as described above. Library (80 pmol) in $200 \mu \mathrm{L}$ sodium phosphate buffer containing $50 \mathrm{mM} \mathrm{NaCl}$ were then added to $1800 \mu \mathrm{L}$ of DMEM cell culture media containing 100 units $/ \mathrm{mL}$ penicillin and $10 \mu \mathrm{g} / \mathrm{mL}$ streptomycin (Gibco 15140148) and 10\% FBS (Gibco 1614079). Medium was then aspirated from a 10-cm plate containing HEK293T cells at $\sim 80 \%$ confluence, and cells were washed with $10 \mathrm{~mL}$ room temperature PBS (Gibco 10010023). PBS was then aspirated and the aptamer library in cell culture media was added to the plate. The plate was gently rocked to spread aptamer solution over adherent cells, and the plate was replaced in a $37^{\circ} \mathrm{C}$ incubator $\left(21 \% \mathrm{O}_{2}, 5 \% \mathrm{CO}_{2}\right)$ and incubated for $30 \mathrm{~min}$ to allow cell interaction, gently agitating every $10 \mathrm{~min}$. Medium was then aspirated and cells scraped into a 1.5-mL microcentrifuge tube. Cells were resuspended and washed $3 \times$ with cold PBS, centrifuging at $500 \times \mathrm{g}$ for $5 \mathrm{~min}$ to collect the cells between washes. The cell pellet was then resuspended in $200 \mu \mathrm{L}$ Qiagen buffer P1 (Qiagen 19051) with gentle pipetting. $200 \mu \mathrm{L}$ Qiagen buffer P2 (Qiagen 19052) was then added and tubes were gently mixed by inversion. Tubes were incubated at room temperature for 5 min to lyse cells, and $200 \mu \mathrm{L}$ Qiagen buffer P3 (Qiagen 19053) was added. Tubes were gently mixed by inversion and then incubated on ice for 15 min to precipitate cellular debris. Tubes were subjected to centrifugation at $17,000 \times \mathrm{g}$ for $5 \mathrm{~min}$, and the supernatant was transferred to a new microcentrifuge tube. $400 \mu \mathrm{L}$ of phenol:chloroform:isoamyl alcohol (25:24:1) was added and tubes were vortexed for $30 \mathrm{~s}$ to perform organic extraction. Tubes were subjected to centrifugation at $17,000 \times \mathrm{g}$ for $5 \mathrm{~min}$, and the upper aqueous layer was transferred to a new microcentrifuge tube. Nucleic acids were precipitated by addition of $700 \mu \mathrm{L}$ isopropanol and chilling on dry ice for $15 \mathrm{~min}$. Tubes were subjected to centrifugation at $17,000 \times$ $\mathrm{g}$ for $15 \mathrm{~min}$ to pellet the nucleic acids, and the pellet was then washed with $250 \mu \mathrm{L}$ cold $70 \%$ 
ethanol, and air dried. Nucleic acids were resuspended in $50 \mu \mathrm{L}$ of sodium phosphate buffer $(\mathrm{pH}$ 6.5) containing $50 \mathrm{mM} \mathrm{NaCl}$, and biotinylated DNA immobilized on M-270 streptavidin Dynabeads, followed by high salt wash, alkaline wash, resuspension, and qPCR quantification, as described above. Following qPCR quantification, analytical PCR was performed to optimize the cycle number used in a large-scale PCR. For a single 2000- $\mu \mathrm{L}$ large-scale PCR reaction, the following volumes of reagent were used: $200 \mu \mathrm{L}$ of $10 \times$ Taq polymerase buffer (Invitrogen cat\# 18067017), $200 \mu \mathrm{L}$ of $10 \times\left(1 \mathrm{mg} / \mathrm{mL}\right.$ ) BSA (NEB B900S), $160 \mu \mathrm{L} 50 \mathrm{mM} \mathrm{MgCl}_{2}, 160 \mu \mathrm{L}$ of 2.5 $\mathrm{mM}$ (each) dNTP mix, $200 \mu \mathrm{L}$ of $5 \mu \mathrm{M}$ forward primer LJM-5304, $200 \mu \mathrm{L}$ of $5 \mu \mathrm{M}$ LJM-5318, $810 \mu \mathrm{L}$ water, $40 \mu \mathrm{L}$ Taq DNA polymerase (Invitrogen 10342020), and $43 \mu \mathrm{L}$ of recovered aptamer library immobilized on M-270 streptavidin Dynabeads. PCR reagents were mixed gently by inversion, aliquoted into PCR tubes, and then subjected to the determined optimal number of thermal cycles, consisting of $30 \mathrm{sec}$ at $95{ }^{\circ} \mathrm{C}$ followed by $90 \mathrm{sec}$ at $70{ }^{\circ} \mathrm{C}$. Amplified DNA was pooled into a single tube and combined with 0.1 equivalent of $3 \mathrm{M} \mathrm{NaOAc}$ and 1 equivalent volume of isopropanol. Samples were mixed and then chilled on dry ice for $15 \mathrm{~min}$ to precipitate nucleic acids. Tubes were subjected to centrifugation at $12,000 \times \mathrm{g}$ for $15 \mathrm{~min}$ to pellet the nucleic acids, and the pellet was then washed with $100 \mu \mathrm{L}$ cold $70 \%$ ethanol and air dried. Nucleic acids were resuspended in $40 \mu \mathrm{L}$ water and combined with $160 \mu \mathrm{L}$ deionized formamide. Samples were heated to $90{ }^{\circ} \mathrm{C}$ for $5 \mathrm{~min}$ to denature, and nucleic acids subjected to electrophoresis through a $10 \%$ denaturing polyacrylamide gel (19:1 acryl:bisacrylamide, containing $7 \mathrm{M}$ urea), and purified as described above.

\subsection{Aptamer cloning and sequencing}

After 8 rounds in vitro selection for karyophilic DNA aptamers, recovered DNA libraries

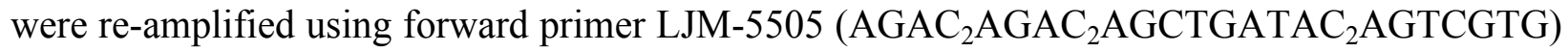
and reverse primer LJM-5319 (TCAG $\left.\mathrm{TG}_{2} \mathrm{AGCAG}_{2} \mathrm{TG}_{2} \mathrm{CT}_{2} \mathrm{G}_{2} \mathrm{CGTA}\right)$ to facilitate cloning of PCR products. For re-amplification, the following volumes of reagents were used: $40 \mu \mathrm{L} 10 \times$ Taq DNA polymerase buffer (Invitrogen 18067017), $40 \mu \mathrm{L} 10 \times(1 \mathrm{mg} / \mathrm{mL}$ ) BSA (NEB B900S), $32 \mu \mathrm{L}$ $50 \mathrm{mM} \mathrm{MgCl} 2,32 \mu \mathrm{L} 2.5 \mathrm{mM}$ (each) dNTP, $40 \mu \mathrm{L} 5 \mu \mathrm{M}$ forward primer LJM-5505, $40 \mu \mathrm{L} 5 \mu \mathrm{M}$ reverse primer LJM-5319, $167 \mu \mathrm{L}$ water, $8 \mu \mathrm{L}$ Taq DNA polymerase (Invitrogen 10342020), and $0.7 \mu \mathrm{L}$ of recovered aptamer library. Library was then amplified for the determined optimal number of PCR cycles, with each cycle consisting of $30 \mathrm{~s}$ at $95{ }^{\circ} \mathrm{C}$, followed by $75 \mathrm{~s}$ at $55^{\circ} \mathrm{C}$, and 
$120 \mathrm{~s}$ at $72{ }^{\circ} \mathrm{C}$. PCR product was then purified by ethanol precipitation and resuspended in $10 \mu \mathrm{L}$ water. Purified DNA product $(3 \mu \mathrm{L})$ was then ligated into pGEM T-Easy vector system (Promega A1360) by combining PCR product with $5 \mu \mathrm{L}$ of $2 \times$ rapid ligation buffer, $1 \mu \mathrm{L}$ pGEM T-Easy vector (50 ng), and $1 \mu \mathrm{L}$ of T4 DNA ligase (3 Weiss units), incubating for $1 \mathrm{~h}$ at room temperature. Ligated vector $(8 \mu \mathrm{L})$ was then electroporated into $170 \mu \mathrm{L}$ of electrocompetent DH5 $\alpha$ cells. LB medium $(500 \mu \mathrm{L})$ was immediately added and cells were allowed to recover at $37^{\circ} \mathrm{C}$ for $1 \mathrm{~h}$ on an orbital shaker. Solutions of transformed bacteria were then spread onto LB agar plates containing carbenicillin/IPTG/X-gal, and colonies grown overnight at $37^{\circ} \mathrm{C}$. White colonies were then picked from the plate and grown overnight in $5 \mathrm{~mL}$ liquid LB culture. Plasmids DNA was isolated (Qiagen 10023 ) and $5 \mu \mathrm{L}$ plasmid solution was combined with $1 \mu \mathrm{L} 1.6 \mu \mathrm{M}$ T7 promoter primer and subjected to Sanger DNA sequencing. This identified two aptamer clones, termed clone 1 and clone 2. A randomly-selected clone from the naïve library was also sequenced: control, $\mathrm{AGAC}_{2} \mathrm{AGAC}_{2} \mathrm{AGCTGATAC}_{2} \mathrm{AG}-$

TCGTGAGA $_{2}$ TCGC $_{2}$ ACTA $_{2} \mathrm{G}_{2}$ TGCAGTATGTATCTG $_{2}$ TCACAT $_{2}$ CTGACTATC $_{2}$ TGTGA $_{2} \mathrm{~T}$ ACGC2 $\mathrm{A}_{2} \mathrm{GC} 2 \mathrm{AC}_{2} \mathrm{TGCTC}_{2} \mathrm{TC}_{2}$ ).

For high-throughput sequencing, recovered aptamer libraries were re-amplified by PCR prior to library preparation. The following volumes of reagents were used: $10 \mu \mathrm{L} 10 \times$ Taq DNA

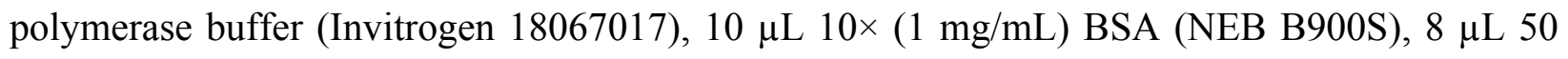
$\mathrm{mM} \mathrm{MgCl2,} 8 \mu \mathrm{L} 2.5 \mathrm{mM}$ (each) dNTP, $10 \mu \mathrm{L} 5 \mu \mathrm{M}$ forward primer LJM-5505, $10 \mu \mathrm{L} 5 \mu \mathrm{M}$ reverse primer LJM-5319, $41 \mu \mathrm{L}$ water, $2 \mu \mathrm{L}$ Taq DNA polymerase (Invitrogen 10342020), and 1 $\mu \mathrm{L}$ of $125 \mathrm{nM}$ recovered aptamer library. Library was then amplified for 7 PCR cycles, with each cycle consisting of $60 \mathrm{~s}$ at $94{ }^{\circ} \mathrm{C}$, followed by $75 \mathrm{~s}$ at $55{ }^{\circ} \mathrm{C}$, and $120 \mathrm{~s}$ at $72{ }^{\circ} \mathrm{C} .40 \mu \mathrm{L}$ of reamplified library was then combined with $72 \mu \mathrm{L}$ of AMPure XP beads (Beckman Coulter A63880) and incubated at room temperature for 10 minutes. Supernatant was aspirated and the beads washed $2 \mathrm{X}$ with $80 \% \mathrm{EtOH}$ prior to drying at 50 degrees for 10 minutes. Purified DNA was eluted from the beads with $25 \mu \mathrm{L}$ of Qiagen EB. High-throughput sequencing libraries were then prepared using the Rubicon Genomics ThruPLEX 48D DNA-seq kit. Following library preparation, libraries were again purified using AMPure XP beads, and then $17 \mu \mathrm{L}$ was submitted to the Mayo Clinic Sequencing Core for high-throughput paired-end 150 cycle sequencing on a MiSeq instrument. Sequencing data were then analyzed using AptaSuite software ${ }^{1}$ 


\subsection{Synthetic oligonucleotides for characterization studies}

Synthetic oligonucleotides LJM-5587 (ctl; $\mathrm{AGAC}_{2} \mathrm{AGAC}_{2} \mathrm{AGCTGATAC}_{2} \mathrm{AGTCGTG-}$

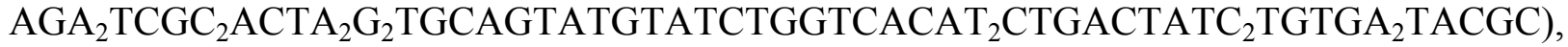
LJM-5588 (clone 1; AGAC $_{2} \mathrm{AGAC}_{2} \mathrm{AGCTGATAC}_{2} \mathrm{AGTCGTGTACTAGTG}_{2} \mathrm{CGTAG}_{2} \mathrm{AT}$ $\mathrm{A}_{2}$ TAGCTATCACT $\mathrm{AGCGA}_{2} \mathrm{GTGCTA}_{2} \mathrm{GTG}_{3} \mathrm{C}_{2} \mathrm{ATACTACGC}$ ), and LJM-5589 (clone 2; $\mathrm{AGAC}_{2} \mathrm{AGAC}_{2} \mathrm{AGCTGATAC}_{2} \mathrm{AGTCGTG}_{2} \mathrm{TATGC}_{5} \mathrm{TGTG}_{2} \mathrm{C}_{2} \mathrm{GTAT}_{2} \mathrm{CA}_{2} \mathrm{G}_{2} \mathrm{AGTA}_{2} \mathrm{G}_{2} \mathrm{ACG}_{2} \mathrm{~T}$ $\mathrm{GT}_{2} \mathrm{ACT}_{2} \mathrm{ACGT}_{2} \mathrm{G}_{2} \mathrm{TATACGC}$ ) were generated for downstream studies. These sequences are truncations of the full length control, clone 1, and clone 2 described above with 21 3' nucleotides removed to facilitate oligonucleotide synthesis.

\subsection{Aptamer thermal melting studies}

Thermal denaturation of oligonucleotide folded structures was performed in $140 \mathrm{mM} \mathrm{Na}^{+}$, 4.5 $\mathrm{mM} \mathrm{K}^{+}, 1.5 \mathrm{mM} \mathrm{Ca}^{2+}$ at $1 \mu \mathrm{M}$ oligonucleotide concentration. Samples were folded by heating to $90^{\circ} \mathrm{C}$ for $5 \mathrm{~min}$ and snap cooling on ice, and then loaded into quartz cuvettes with $1 \mathrm{~cm}$ path length. Absorbance measurements were obtained using a Cary $100 \mathrm{UV}$-vis spectrophotometer over the temperature range of $4-90^{\circ} \mathrm{C}$, at increments of $1^{\circ} \mathrm{C}$, with temperature rate change of $1{ }^{\circ} \mathrm{C} / \mathrm{min}$. Mathematical analysis of thermal denaturation curves was conducted in $\mathrm{R}$ using methods previously described ${ }^{2}$.

\subsection{Nuclease susceptibility characterization}

Whole cell extract was prepared from 10E6 HEK293T cells using a method that was previously-described ${ }^{3}$. Protein concentration in whole cell extract was estimated using UV absorbance measurements, as previously described ${ }^{4}$. Oligonucleotides labeled with 5' FITC were prepared at $200 \mathrm{nM}$ in $1 \times$ NEB CutSmart buffer (NEB B7204S) supplemented with $1 \mathrm{mM} \mathrm{CaCl}_{2}$, and folded by heating to $90^{\circ} \mathrm{C}$ and snap cooling on ice. Whole cell extract (100 $\left.\mu \mathrm{g}\right)$ was added to $220 \mu \mathrm{L}$ of folded oligonucleotide on ice. Aliquots $(20 \mu \mathrm{L})$ were incubated at $37^{\circ} \mathrm{C}$ for various lengths of time. Reactions were stopped by freezing samples on dry ice. LDS buffer ( $7 \mu \mathrm{L}$ of $4 \times$ stock) was added to the frozen samples, and then samples were heated to $90^{\circ} \mathrm{C}$ for 5 min to inactivate enzyme activities. Samples were subjected to electrophoresis on a denaturing 10\% polyacrylamide gel (19:1 acrylamide:bisacrylamide, $7.5 \mathrm{M}$ urea) with $0.5 \times \mathrm{TBE}$ running buffer at 
$600 \mathrm{~V}$ for $30 \mathrm{~min}$. Fluorescent oligonucleotides were imaged using a Typhoon fluorometric imager.

\subsection{Chemical reactivity analysis of aptamer native structures}

Solutions of LJM-5588 and LJM-5589 labeled with 5' FITC were prepared at $2 \mu \mathrm{M}$ concentration in PBS. Samples were heated to $90^{\circ} \mathrm{C}$ for $5 \mathrm{~min}$ to denature and then placed on ice. Solutions containing the same oligonucleotides in $8 \mathrm{M}$ urea were also prepared and denatured by heating to $90^{\circ} \mathrm{C}$ for $5 \mathrm{~min}$.

For dimethyl sulfate (DMS) reactivity (G>A reaction), $200 \mu \mathrm{L}$ aptamer solution was combined with $2 \mu \mathrm{L}$ DMS (Sigma Aldrich D186309) and incubated at room temperature for 5 min. The reaction was quenched by addition of $200 \mu \mathrm{L}$ stop solution (1 M $\beta$-mercaptoethanol, 1 M Tris-OAc $\mathrm{pH} 7.5,1.5 \mathrm{M} \mathrm{NaOAc}, 50 \mathrm{mM} \mathrm{MgOAc}_{2}$, and $1 \mathrm{mM}$ EDTA), and then combined with $2 \mu \mathrm{L}$ tRNA $(10 \mathrm{mg} / \mathrm{mL})$ as carrier. Samples were precipitated by adding $1 \mathrm{~mL}$ absolute ethanol and chilling on dry ice for $15 \mathrm{~min}$. Samples were subjected to centrifugation at $17,000 \times \mathrm{g}$ for 15 mi and DNA pellets were washed with $250 \mu \mathrm{L}$ of cold $70 \%$ ethanol. Pellets were air dried and resuspended in $60 \mu \mathrm{L} / 10 \mathrm{mM}$ sodium phosphate buffer ( $\mathrm{pH}$ 7.0) containing 1 mM EDTA. Samples were heated to $90^{\circ} \mathrm{C}$ for $15 \mathrm{~min}$ and then chilled on ice. A solution of $1 \mathrm{~N} \mathrm{NaOH}(6 \mu \mathrm{L})$ was then added and samples were heated to $90{ }^{\circ} \mathrm{C}$ for $30 \mathrm{~min}$. Samples were then cooled and mixed with $50 \mu \mathrm{L}$ glycogen $(5 \mathrm{mg} / \mathrm{mL}$ stock). Samples were precipitated from $500 \mu \mathrm{L}$ of absolute ethanol as previously described and then centrifuged at $17,000 \times \mathrm{g}$ for $15 \mathrm{~min}$ and DNA pellets were washed with $250 \mu \mathrm{L}$ cold $70 \%$ ethanol. Pellets were then air dried and resuspended in $15 \mu \mathrm{L}$ water. Deionized formamide ( $45 \mu \mathrm{L})$ was then added and samples were heated to $90^{\circ} \mathrm{C}$ for 5 min to denature.

For $\mathrm{KMnO}_{4}$ reactivity studies, $200 \mu \mathrm{L}$ aptamer solution was combined with $20 \mu \mathrm{L} 160 \mathrm{mM}$ $\mathrm{KMnO}_{4}$ (Sigma Aldrich 223468) and incubated at room temperature for $5 \mathrm{~min}$. The reaction was quenched by addition of $25 \mu \mathrm{L} \beta$-mercaptoethanol. Following quenching, samples were combined with $25 \mu \mathrm{L} 500 \mathrm{mM}$ EDTA, mixed, and placed on ice. Samples were precipitated by adding $1 \mathrm{~mL}$ absolute ethanol and processed as described above. Pellets were air dried and resuspended in 300 $\mu \mathrm{L} 10 \%$ (v/v) piperidine (Simga 104094). Samples were heated to $90^{\circ} \mathrm{C}$ for $30 \mathrm{~min}$ and frozen on dry ice. Solvent was then removed by lyophilization, and samples resuspended in $50 \mu \mathrm{L}$ water. 
Samples were precipitated from $250 \mu \mathrm{L}$ absolute ethanol and processed as described above. Water $(15 \mu \mathrm{L})$ and deionized formamide $(45 \mu \mathrm{L})$ was then added and samples were heated to $90^{\circ} \mathrm{C}$ for 5 min to denature.

Samples $(20 \mu \mathrm{L})$ from DMS and $\mathrm{KMnO}_{4}$ footprinting studies were subjected to electrophoresis through $16 \%$ denaturing polyacrylamide (19:1 acrylamide:bisacrylamide) sequencing gels $(7.5 \mathrm{M}$ urea) in $0.5 \times$ TBE running buffer. Electrophoresis was for $3.5 \mathrm{~h}$ at 26 $\mathrm{V} / \mathrm{cm}$ with drying and imaging on a GE Typhoon fluorimeter to detect fluorescence of FITClabelled oligonucleotides. Intensities of bands on gels comparing native and denaturing $\mathrm{KMnO}_{4}$ reactivity patterns were quantified using ImageQuant software, applying a rubber band method for background subtraction.

\subsection{Mung Bean nuclease profiling of aptamer native structures}

Oligonucleotides were prepared at $2 \mu \mathrm{M}$ concentration in $1 \times$ Mung Bean nuclease reaction buffer (NEB B0250). Samples were heated to $90^{\circ} \mathrm{C}$ for $5 \mathrm{~min}$ and snap cooled on ice. $1 \mu \mathrm{L}$ of Mung Bean nuclease (NEB M0250S) was added per $200 \mu \mathrm{L}$ reaction. Samples were mixed by pipette and then incubated at $30^{\circ} \mathrm{C}$ for $60 \mathrm{~min}$. Samples were transitioned to ice, combined with $20 \mu \mathrm{L} 3 \mathrm{M} \mathrm{NaOAc}$ and $4 \mu \mathrm{L}$ of stDNA $(5 \mathrm{mg} / \mathrm{mL})$, and mixed by vortex. Nucleic acid was precipitated by the addition of $1000 \mu \mathrm{L}$ of EtOH and chilling on dry ice for $15 \mathrm{~min}$. Samples were centrifuged at $17,000 \times \mathrm{g}$ for $15 \mathrm{~min}$, supernatant removed, and pellets washed with $500 \mu \mathrm{L} 70 \%$ EtOH. Water $(15 \mu \mathrm{L})$ and deionized formamide $(45 \mu \mathrm{L})$ was then added to re-dissolve DNA and samples were heated to $90^{\circ} \mathrm{C}$ for 5 min to denature. Samples $(20 \mu \mathrm{L})$ from DMS and Mung Bean nuclease studies were subjected to electrophoresis through 16\% denaturing polyacrylamide (19:1 acrylamide:bisacrylamide) sequencing gels $(7.5 \mathrm{M}$ urea) in $0.5 \times \mathrm{TBE}$ running buffer. Electrophoresis was for $3.5 \mathrm{~h}$ at $26 \mathrm{~V} / \mathrm{cm}$ with drying and imaging on a GE Typhoon fluorimeter to detect fluorescence of FITC-labelled oligonucleotides.

\subsection{Proteomic analysis of aptamer-interacting partners}

HEK293T cells were grown in $10-\mathrm{cm}$ plates to $85 \%$ confluence. Media was then aspirated and solutions of 3'-biotinylated LJM-5587, LJM-5588, and LJM-5589 were added to $1 \mu \mathrm{M}$ concentration in $3 \mathrm{~mL}$ DMEM media containing 10\% FBS and Pen/Strep antibiotics. Plates were incubated at $37^{\circ} \mathrm{C}$ for $2 \mathrm{~h}$. Media containing aptamer solutions was aspirated, and the cells were 
trypsinized ( $2 \mathrm{~mL} 0.25 \%$ Trypsin-EDTA; Gibco 25200056), quenched with $8 \mathrm{~mL}$ media, and collected by centrifugation at $3000 \mathrm{rpm}$ for $5 \mathrm{~min}$. Cells were washed twice with $5 \mathrm{~mL}$ PBS. Cells were then resuspended in $5 \mathrm{~mL}$ of PBS containing 3.7\% formaldehyde and incubated at room temperature for $30 \mathrm{~min}$. Cells were collected by centrifugation and resuspended in $1 \mathrm{~mL}$ lysis buffer (10 mM Tris-HCl, pH 7.5, $10 \mathrm{mM} \mathrm{NaCl}, 0.5 \%$ IPEGAL). Cells were then resuspended in 1 $\mathrm{mL}$ lysis buffer (10 mM Tris-HCl, $\mathrm{pH} 7.5,10 \mathrm{mM} \mathrm{NaCl}, 0.5 \%$ IGEPAL), and sonicated twice for 10 s using a Fisher Scientific Sonic Dismembranator 60 probe-type sonicator at power setting \#7, placing samples on ice for $30 \mathrm{~s}$ between sonication rounds. Cross-linked aptamer-protein complexes were then captured on $120 \mu \mathrm{L}$ M-270 streptavidin Dynabeads (Invitrogen 65305), washed twice with binding and wash buffer and once with TE buffer, using a magnet to retain the beads between washes. Beads were then resuspended in $50 \mu \mathrm{L}$ of elution buffer $(10 \mathrm{mM}$ Tris$\mathrm{HCl}, \mathrm{pH} 8.0,10 \mathrm{mM}$ EDTA, $150 \mathrm{mM} \mathrm{NaCl}, 5 \mathrm{mM}$ DTT, 1\% SDS). Beads were then incubated at $65^{\circ} \mathrm{C}$ overnight to reverse formaldehyde cross-links. Eluents were submitted to the Mayo Clinic Proteomics Core Facility for tryptic digestion followed by LC-MS peptide identification and quantification. Identified peptides from all three oligonucleotides (LJM-5587, LJM-5588, and LJM-5589) were compared, and unique proteomic interactions present in each of the three datasets were identified. g:Profiler functional annotation enrichment analysis was then performed on these subsets of unique interactions, as previously described ${ }^{5}$. To assess for differences in expression of aptamer-binding partners among human cell lines, iBAQ non-targeted proteomic quantifications from human cell lines ${ }^{6}$ were median-normalized, followed by determination of $\log _{2}$ (fold-change) in proteomic abundance for HEK293 vs. HeLa or HEK293 vs. HepG2, and filtering to retain only the nominated aptamer-binding partners that were identified empirically. Protein co-expression networks for aptamer proteomic binding partners were extracted from the STRING database and analyzed for enrichment of co-expression interactions relative to a random collection of the same number of proteins?

\subsection{Cellular Fractionation and qPCR Detection of Aptamer Localization}

Cells were plated at a density of $\sim 28,500$ cells $/ \mathrm{cm}^{2} 6$-well plates with $1 \mathrm{~mL}$ DMEM medium containing 10\% FBS and Penn/Strep antibiotics $24 \mathrm{~h}$ in advance of aptamer treatment. Media was then aspirated and aptamer was added to cultures in $242 \mu \mathrm{L}$ fresh media at a final concentration of $1 \mu \mathrm{M}$. Cells were then cultured for $2 \mathrm{~h}$ before fractionation. 
Cell fractionation was performed according to a protocol for nuclear extraction from Abcam. Cells were scraped from each well into $500 \mu \mathrm{L}$ fractionation buffer (20 mM HEPES, 10 $\mathrm{mM} \mathrm{KCl}, 2 \mathrm{mM} \mathrm{MgCl} 2,1 \mathrm{mM}$ EDTA, $1 \mathrm{mM}$ EGTA, $1 \mathrm{mM} \mathrm{DTT}$ ) and incubated on ice for 15 min. Cells were then lysed by 10 passages through a 27 -gauge needle, incubated on ice for $20 \mathrm{~min}$, and nuclei collected by centrifugation for $5 \mathrm{~min}$ at $720 \times \mathrm{g}$. Supernatant containing the cytoplasmic fraction was collected. The remaining pellet was washed in $500 \mu \mathrm{L}$ fractionation buffer and passed through a 25 -gauge needle 10 times. This material was collected by centrifugation for $10 \mathrm{~min}$ at $720 \times \mathrm{g}$, resuspended in TBS $+0.1 \%$ SDS, and briefly sonicated to homogenize the lysate. Efficiency of fractionation was confirmed by western blotting with antibodies for nuclear protein YY1 (Abcam, ab38422) and cytoplasmic protein MEK1/2 (Cell Signaling Technology, 9122S).

Each fraction was characterized for total protein content by BCA assay (Pierce 23225) and $250 \mu \mathrm{L}$ of each fraction was processed for DNA purification. Aliquots were treated with proteinase K using the Qiagen DNeasy Blood and Tissue Kit (69504), followed by phenol:chloroform extraction and ethanol precipitation. This DNA preparation was used as template for qPCR quantification of aptamer recovery in each cell fraction. Identical forward primer here (LJM-5785, $\mathrm{AGAC}_{2} \mathrm{AGAC}_{2} \mathrm{AGCTGATAC}_{2} \mathrm{AGTCGTG}$ ) and a unique reverse primer for each molecule was used for qPCR. Unique primers were as follows: 1) control- LJM-5786 (GCGTATAC ${ }_{2} \mathrm{~A}_{2} \mathrm{CGTA}_{2} \mathrm{GTA}_{2} \mathrm{CAC}_{2}$ GTGC), 2) clone 1- LJM-5787 (GCGTAGTA$\left.\mathrm{TG}_{2} \mathrm{C}_{3} \mathrm{ACT}_{2} \mathrm{AGCACT}_{2} \mathrm{CGC}\right)$, 3) clone 2- LJM-5788 (GCGTATAC $\mathrm{A}_{2} \mathrm{CGTA}_{2} \mathrm{GTA}_{2} \mathrm{CA}-$ $\mathrm{C}_{2} \mathrm{GTC}_{2}$ ).

\subsection{Knockdown of Cell Uptake Pathways}

HEK293T cells were plated at approximately 30\% confluency in 6-well plates $24 \mathrm{~h}$ in advance of exposure to siRNAs. siRNA SmartPools were used for knockdown of DNM2 (Dharmacon, M-004007), CLTC (Dharmacon, M-004001), CAV1 (Dharmacon, M-003467), PAK1 (Dharmacon, M-003521), and non-targeting siRNA (Dharmacon, D-001210). siRNA pools for dilution to a final concentration of $150 \mathrm{nM}$ were incubated in $100 \mu \mathrm{L}$ fresh media for $5 \mathrm{~min}$ at room temperature along with a similar incubation of $7.5 \mu \mathrm{L}$ Lipofectamine 2000 in $100 \mu \mathrm{L}$ media. Following the 5 min incubation, each $100 \mu \mathrm{L}$ aliquot was mixed before an additional incubation of $20 \mathrm{~min}$. This final $200 \mu \mathrm{L}$ volume was combined with $800 \mu \mathrm{L}$ fresh media and, following aspiration of media in each well, was added to HEK293T cells and incubated at $37^{\circ} \mathrm{C}$ for $3 \mathrm{~h}$. An 
additional $2 \mathrm{~mL}$ of media was then added to each well before incubation for another $69 \mathrm{~h}$, resulting in a 72-h incubation period.

Following incubation with siRNAs, media was aspirated from each well and markers specific to endocytosis pathways of interest were added in fresh media to cells. TransferrinAlexaFluor647 conjugates (Invitrogen, T23366), sensitive to knockdown of CLTC and DNM2, were added to cells at a final concentration of $50 \mu \mathrm{g} / \mathrm{mL}$ in fresh media for $20 \mathrm{~min}$. DextranAlexaFluor647 (Invitrogen, D22914), a marker of PAK1 activity, was added to cells at a final concentration of $75 \mu \mathrm{g} / \mathrm{mL}$ for $1.5 \mathrm{~h}$. Following exposure to each marker, cells were gently washed with PBS and stained with DAPI (Roche, 10236276001). Uptake of each marker under control or knockdown conditions was determined by confocal microscopy on a Zeiss LSM 780 microscope. Aptamer uptake under knockdown conditions was assessed with qPCR as described above. 


\subsection{Supporting Figures}

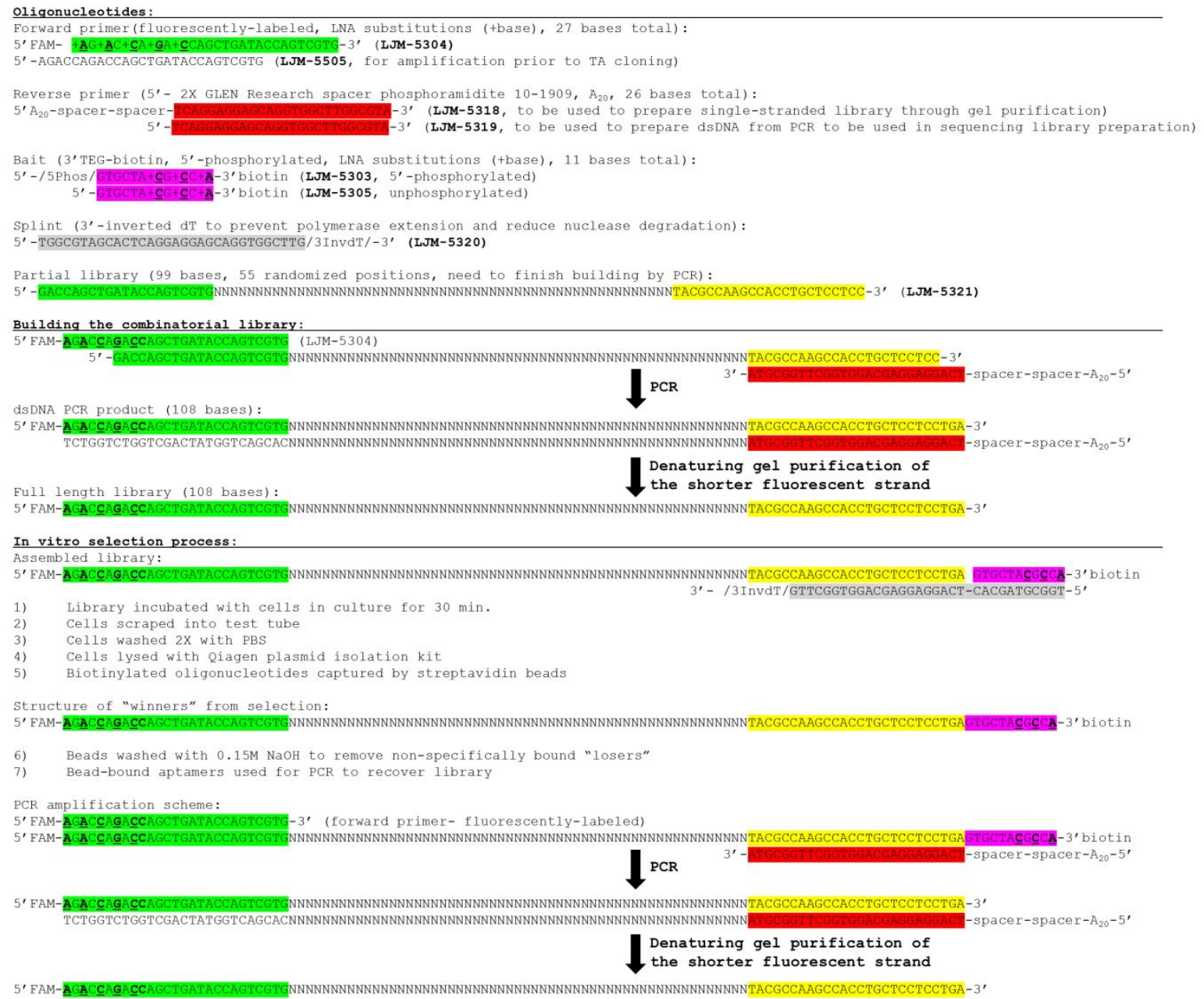

Figure S1. Detailed schematic of oligonucleotide sequences and hybridization strategy used for in vitro selection of karyophilic aptamers. 
A

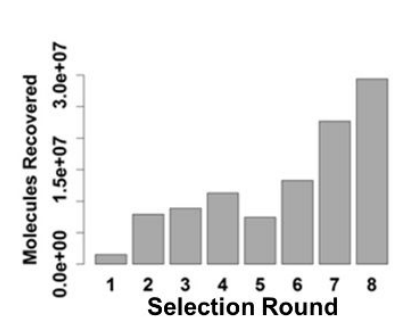

C

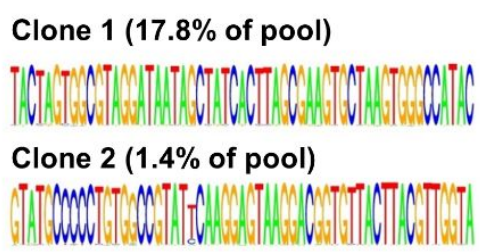

B

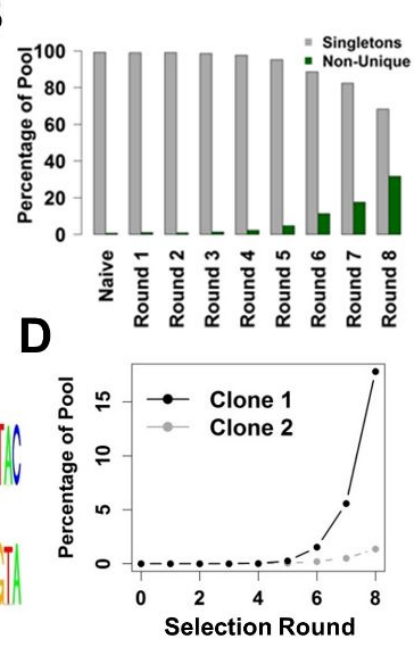

E

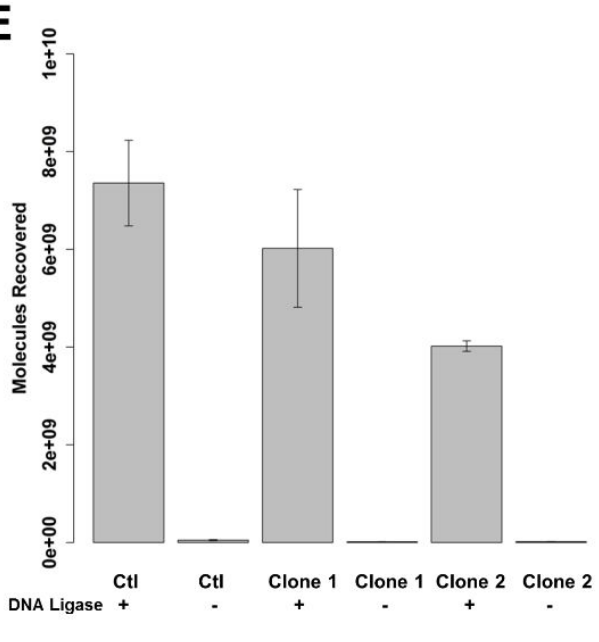

Figure S2. Identification of two karyophilic clones from in vitro selection. A) qPCR quantification of molecules recovered after each round of selection, indicating that the pool becomes enriched for molecules exposed to ligase activity. B) Assessment of percentage the recovered aptamer pool following each round composed of unique or nonunique sequences. C) Identified clones 1 and 2 from selection and percentage of the recovered round 8 pool made up by each clone. D) Percentage of recovered aptamer pools made up of clone 1 or 2 following each round of in vitro selection. E) Assessment of autoligation propensity of DNA ligase-sensitive constructs with clones 1 and 2 incubated either alone or in the presence of T4 DNA ligase. 
A

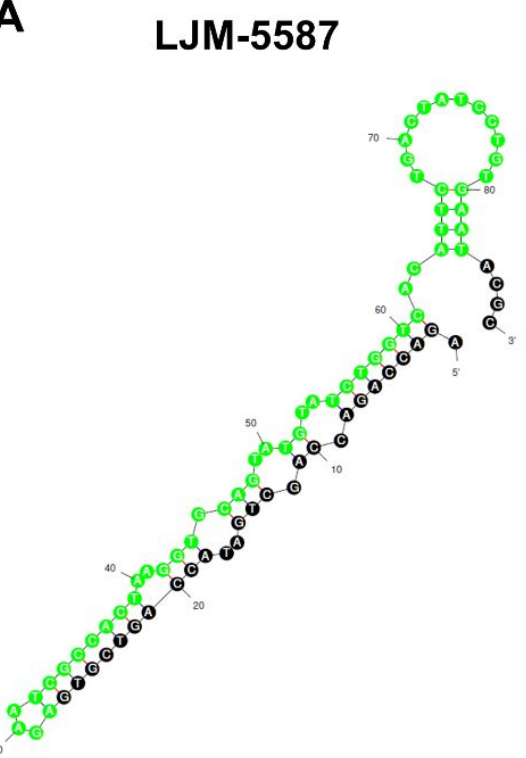

$\Delta \mathbf{G}=-4.79 \mathrm{kcal} / \mathrm{mol}$

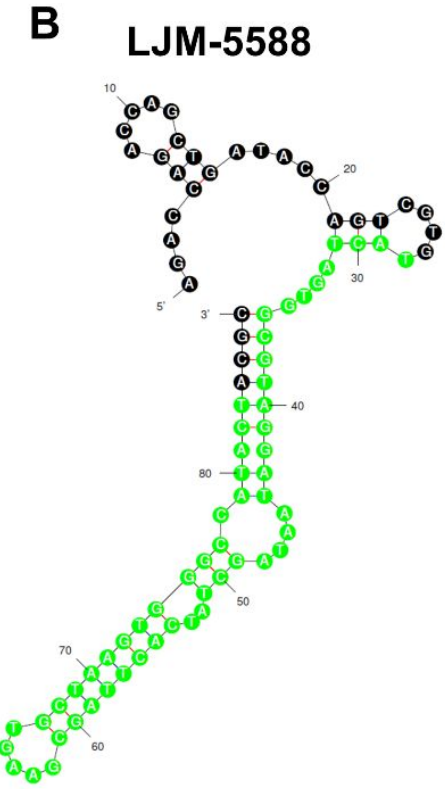

$\Delta \mathbf{G}=-9.95 \mathrm{kcal} / \mathrm{mol}$

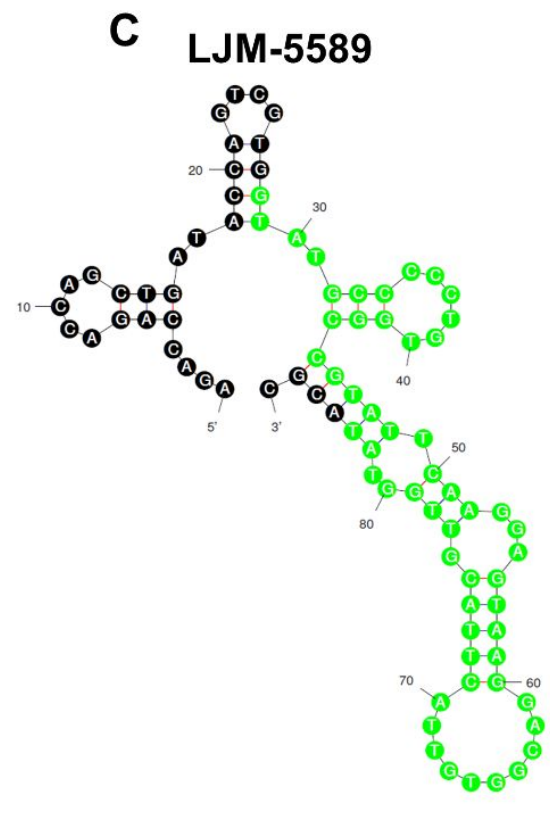

$\Delta \mathbf{G}=-5.60 \mathrm{kcal} / \mathrm{mol}$

Figure S3. Predicted structures and stability of aptamers derived from shortened clones identified by in vitro selection. A) LJM-5587, negative control. B) LJM-5588, derived from clone 1. C) LJM-5589, derived from clone 2. Bases in green are those within the randomized region of the library, and those in black are located within constant primer regions. Gibbs free energy is predicted by $\mathrm{mFold}$ under physiologically-relevant concentrations of monovalent and divalent cations $\left(145 \mathrm{mM} \mathrm{Na}^{+}, 1.5 \mathrm{mM} \mathrm{Mg}^{2+}\right)$ at $37^{\circ} \mathrm{C}$. 

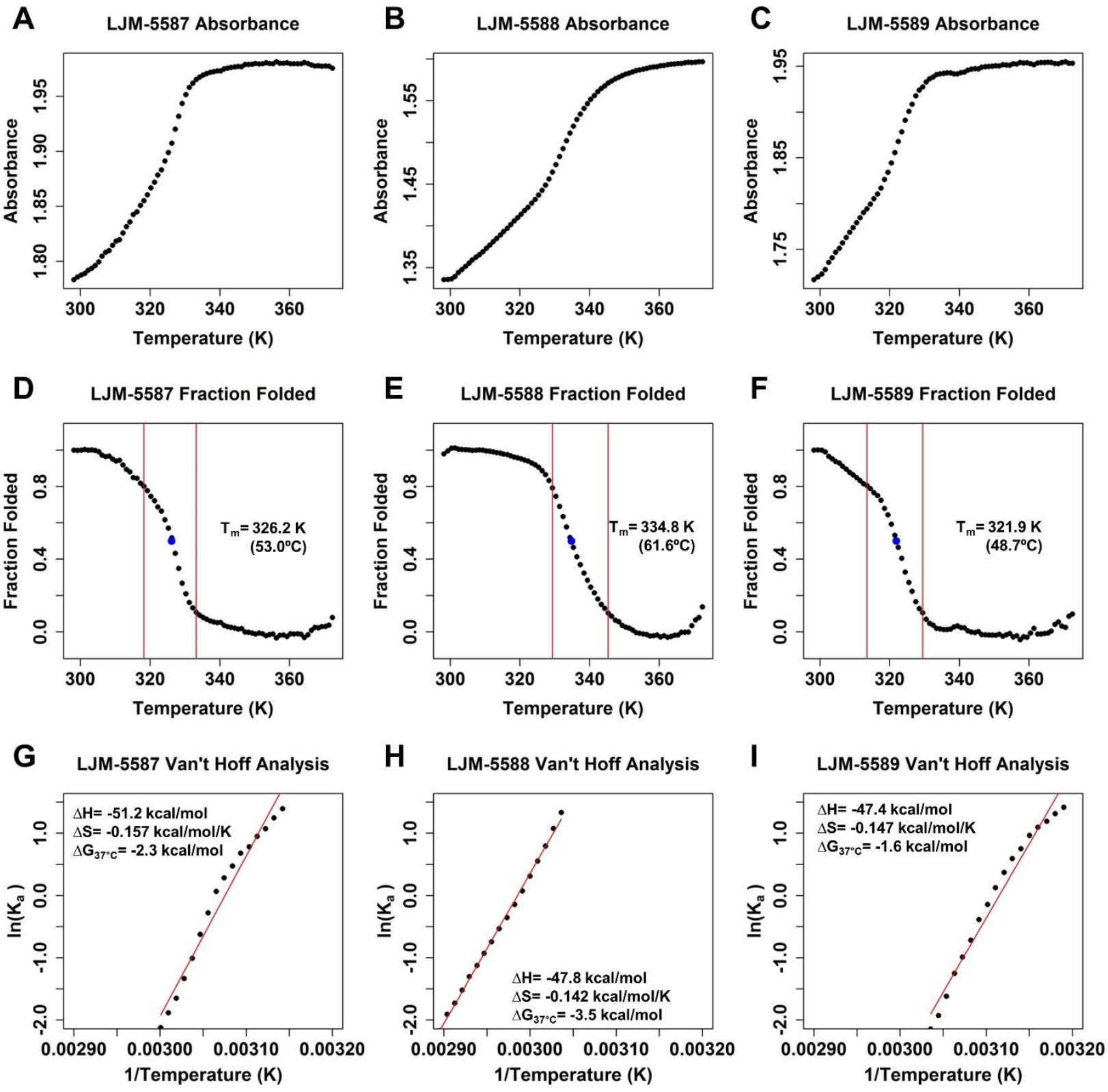

Figure S4. Thermodynamic analysis of oligonucleotide melting under physiologic ion conditions $\left(140 \mathrm{mM} \mathrm{Na}^{+}\right.$, 4.5 $\mathrm{mM} \mathrm{K}^{+}, 1.5 \mathrm{mM} \mathrm{Ca}^{2+}$ ) using absorption spectrometry. A-C) DNA absorbance at $260 \mathrm{~nm}$ plotted as a function of temperature. D-F) Fraction of oligonucleotide species folded plotted as a function of temperature. Red vertical lines indicate region of the melt curve used for van't Hoff analysis. Melting temperature is indicated. G-I) van't Hoff analysis of change in equilibrium constant as a function of temperature. Calculated changes in enthalpy and entropy are shown, as well as Gibbs free energy change of folding at $37^{\circ} \mathrm{C}$. 


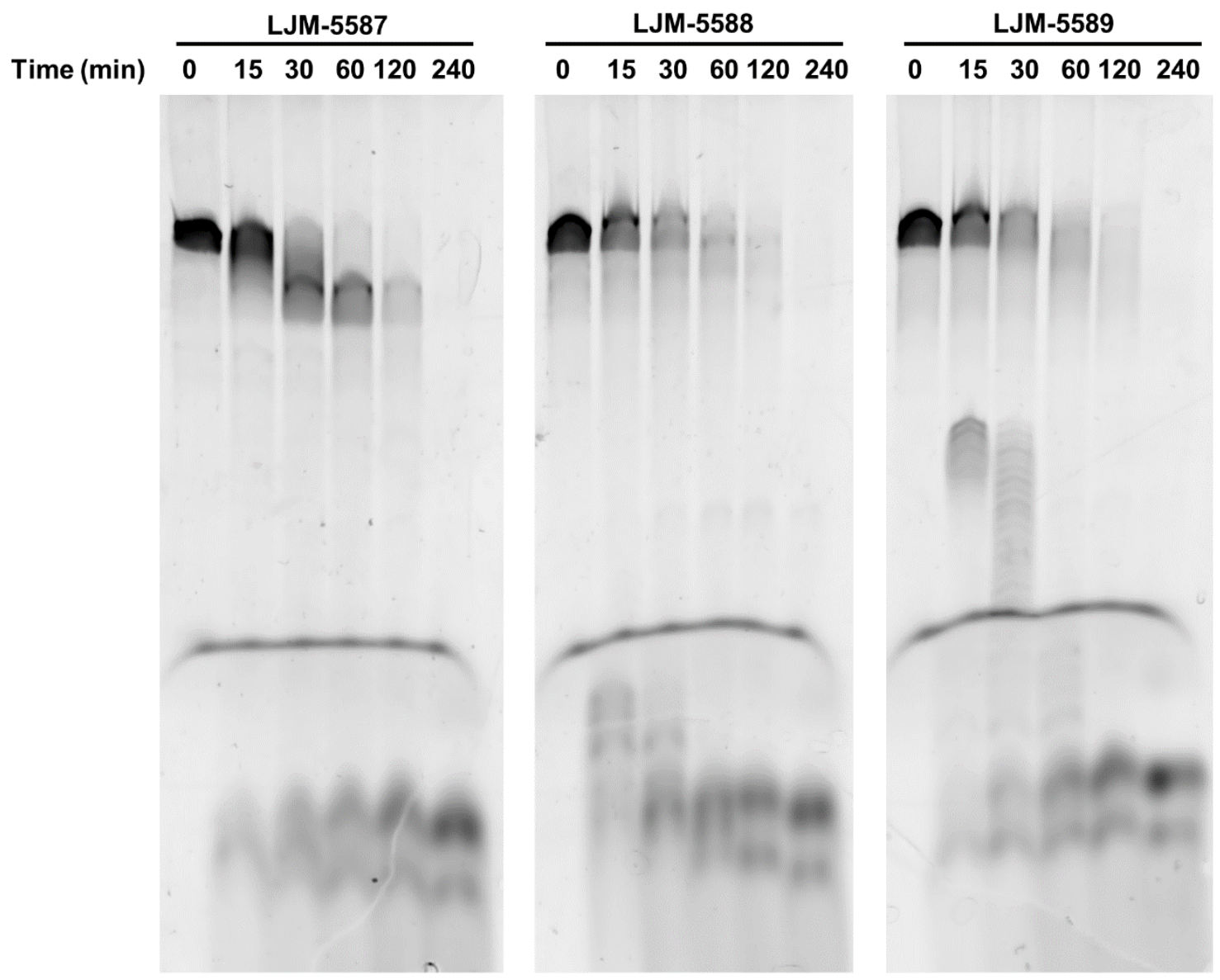

Figure S5. Characterization of oligonucleotide degradation susceptibility by endogenous nucleases in HEK293T whole cell extract. Denaturing polyacrylamide gel electrophoresis of 5'-FAM-conjugated oligonucleotides after incubation with HEK293T whole cell extract for variable time. 

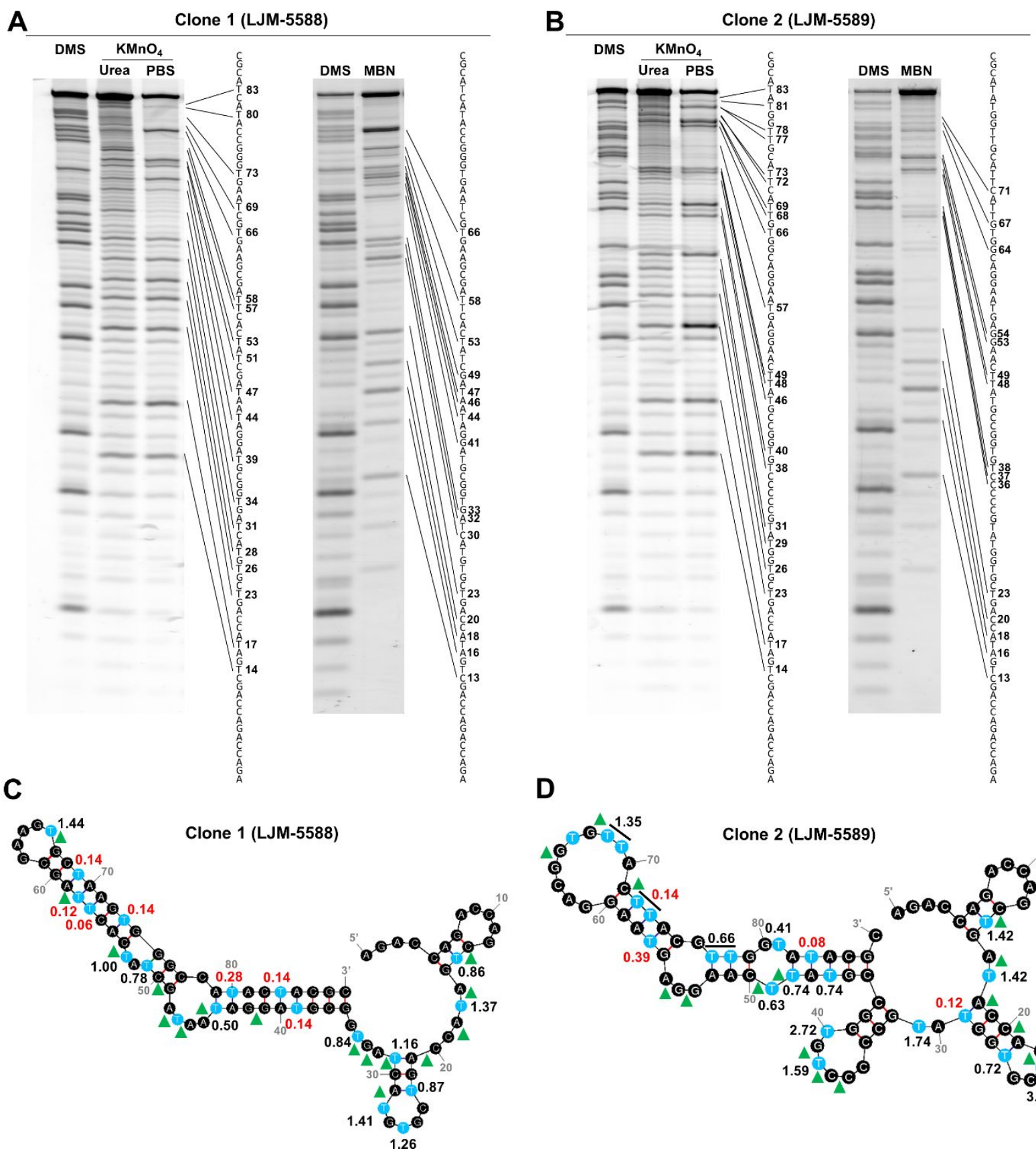

D

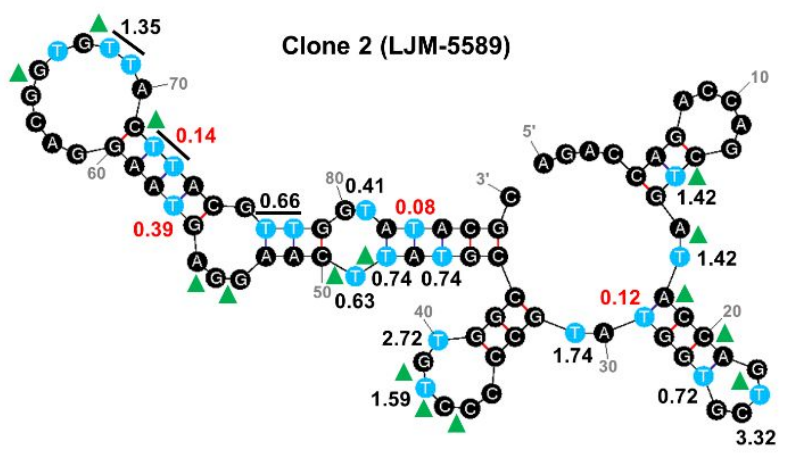

Figure S6. Structural characterization of karyophilic aptamers. A,B) Denaturing gel electrophoresis of aptamer cleavage fragments generated by dimethyl sulfate (DMS) or $\mathrm{KMnO}_{4}$ chemistries followed by treatment with strong alkali, or enzymatic cleavage by Mung Bean nuclease (MBN). DMS treatment results in production of G>A sequencing ladder. $\mathrm{KMnO}_{4}$ treatment results in cleavage at thymine nucleotides and is enhanced in single-stranded regions. Comparison of thymine nucleotide cleavage patterns between native (PBS) and denatured (urea) conditions allows for identification of duplex regions in the native aptamer structure. MBN enzymatic cleavage occurs preferentially in single-stranded regions. C,D) Calculated protection ratios for $\mathrm{KMnO}_{4}$ assay (native/denaturing reactivity) overlaid upon predicted aptamer secondary structure for C) LJM-5588 or D) LJM-5589. Positions with impressive protection to $\mathrm{KMnO}_{4}$ reactivity under native conditions are indicated in red. Positions susceptible to MBN enzymatic cleavage are indicated by green triangles. 

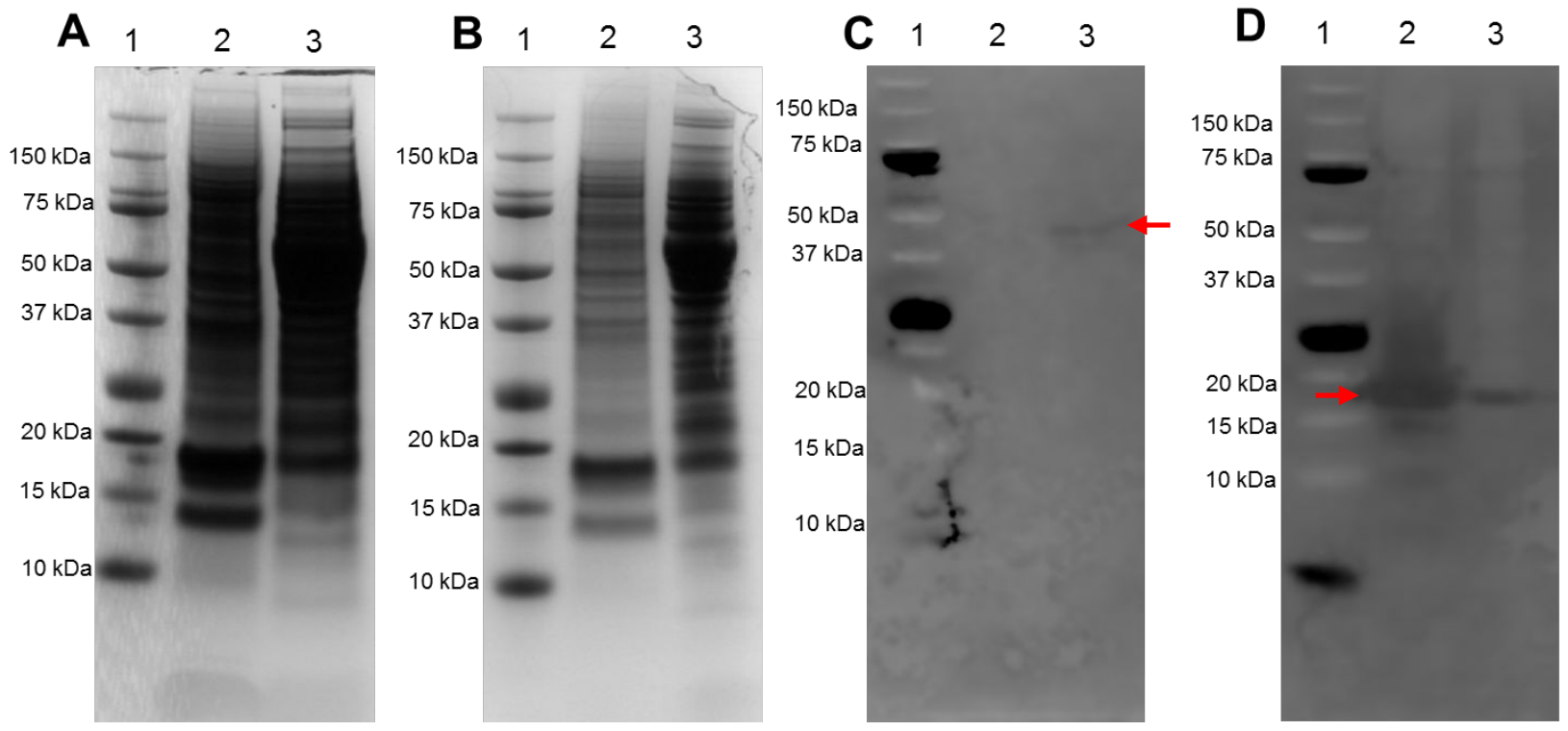

Figure S7. Confirmation of cellular fractionation. A) Total protein isolated from fractionation of HEK293T cells as loaded for Western blotting. Protein is indicated by Coomassie stain. B) 3-fold dilution of total protein loaded for Western blotting. Protein is indicated by Coomassie stain. C) Western blot confirmation of MEK1/2 (43 kDa) in cytoplasmic fraction. MEK1/2 is not present in the nuclear fraction. D) Western blot confirmation of histone H3 (17 $\mathrm{kDa}$ ) in nuclear fraction. Histone $\mathrm{H} 3$ is present in small quantity in the cytoplasmic fraction. For all gels, Lane 1Biocompare Precision Plus Dual Color protein ladder. Lane 2-Nuclear fraction. Lane 3-Cytoplasmic fraction. 

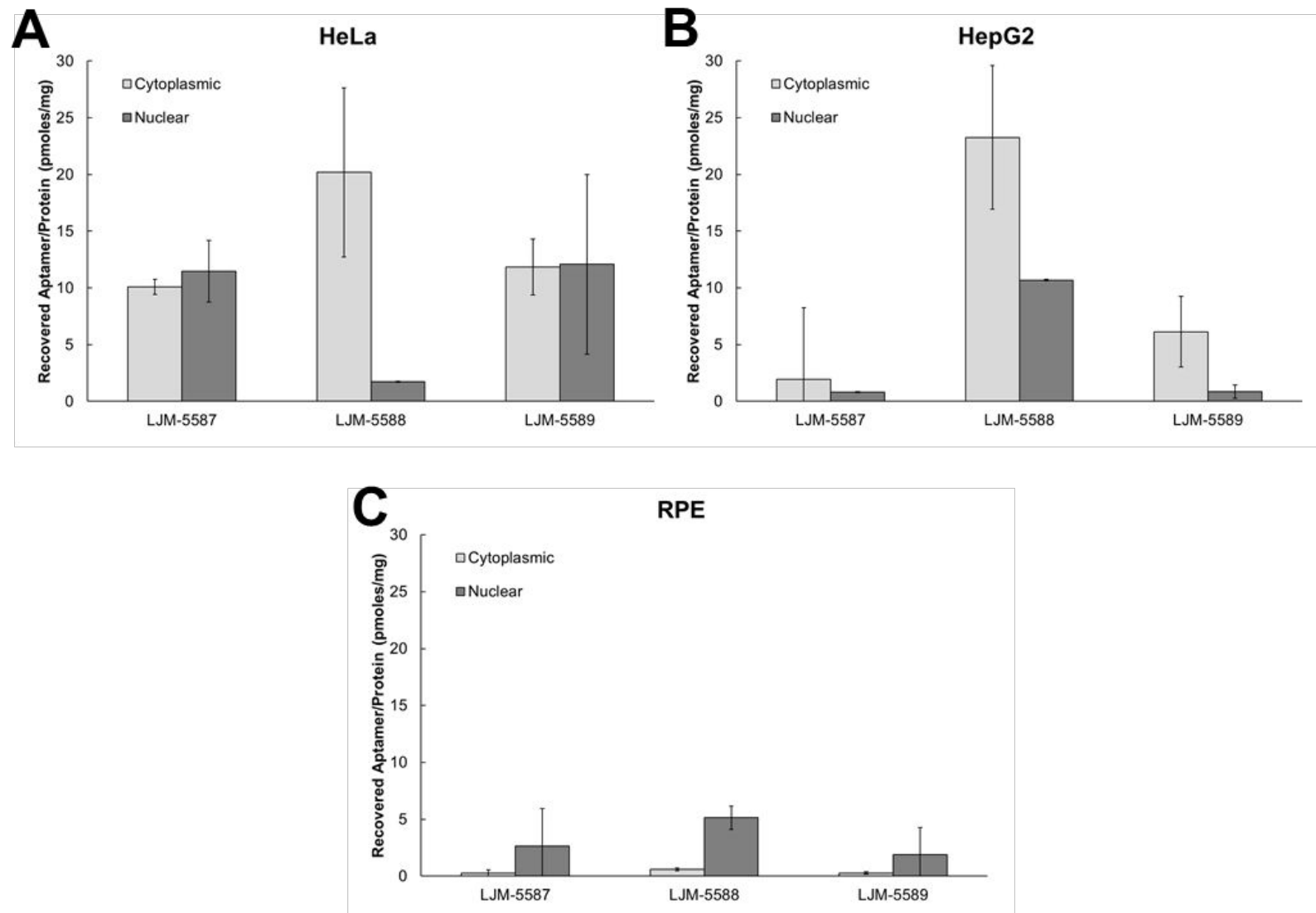

Figure S8. qPCR quantification of aptamer uptake in various cell lines. Aptamer localization was quantified in A) HeLa, B) HepG2, and 3) RPE cells. 
A

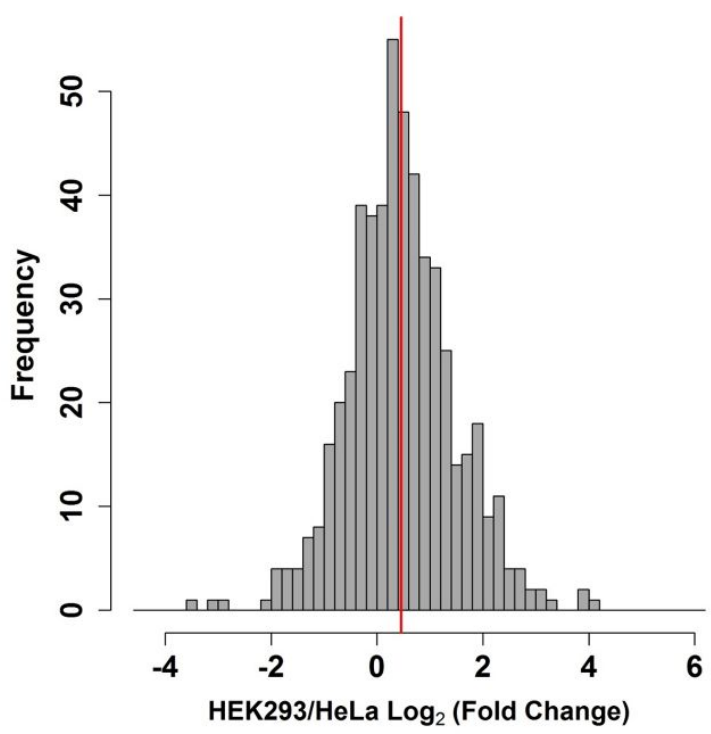

B

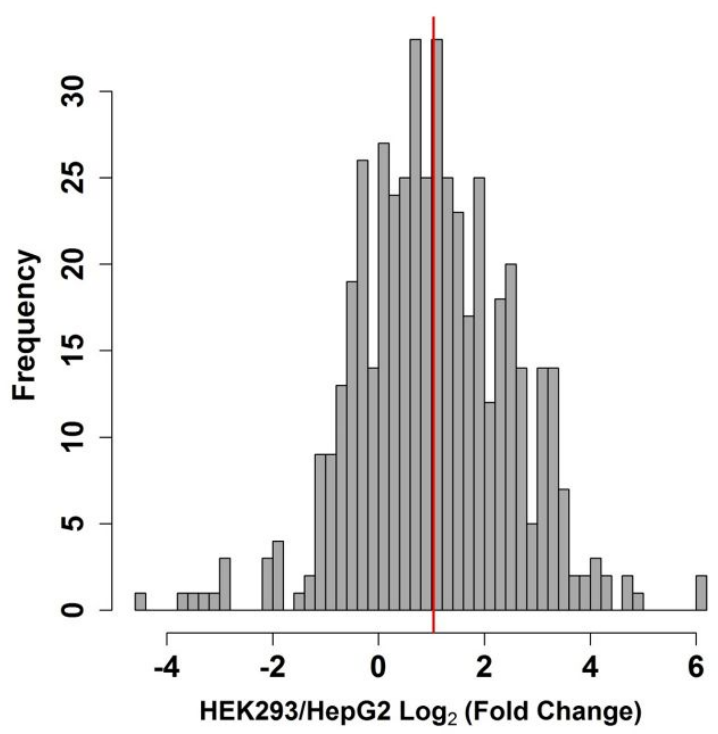

Figure S9. Relative proteomic expression of aptamer-binding targets among human cell lines. $\log _{2}$ (fold-change) in protein expression taken as the ratio of median-normalized iBAQ proteomic quantifications for HEK293 relative to HeLa (A) and HepG2 (B) cell lines, shown for the subset of proteins empirically nominated as putative aptamer binding partners. Vertical red lines indicated mean values: $\log _{2}(\mathrm{HEK} 293 / \mathrm{HeLa})=0.45, \log _{2}(\mathrm{HEK} 293 / \mathrm{HepG} 2)=1.04$. 


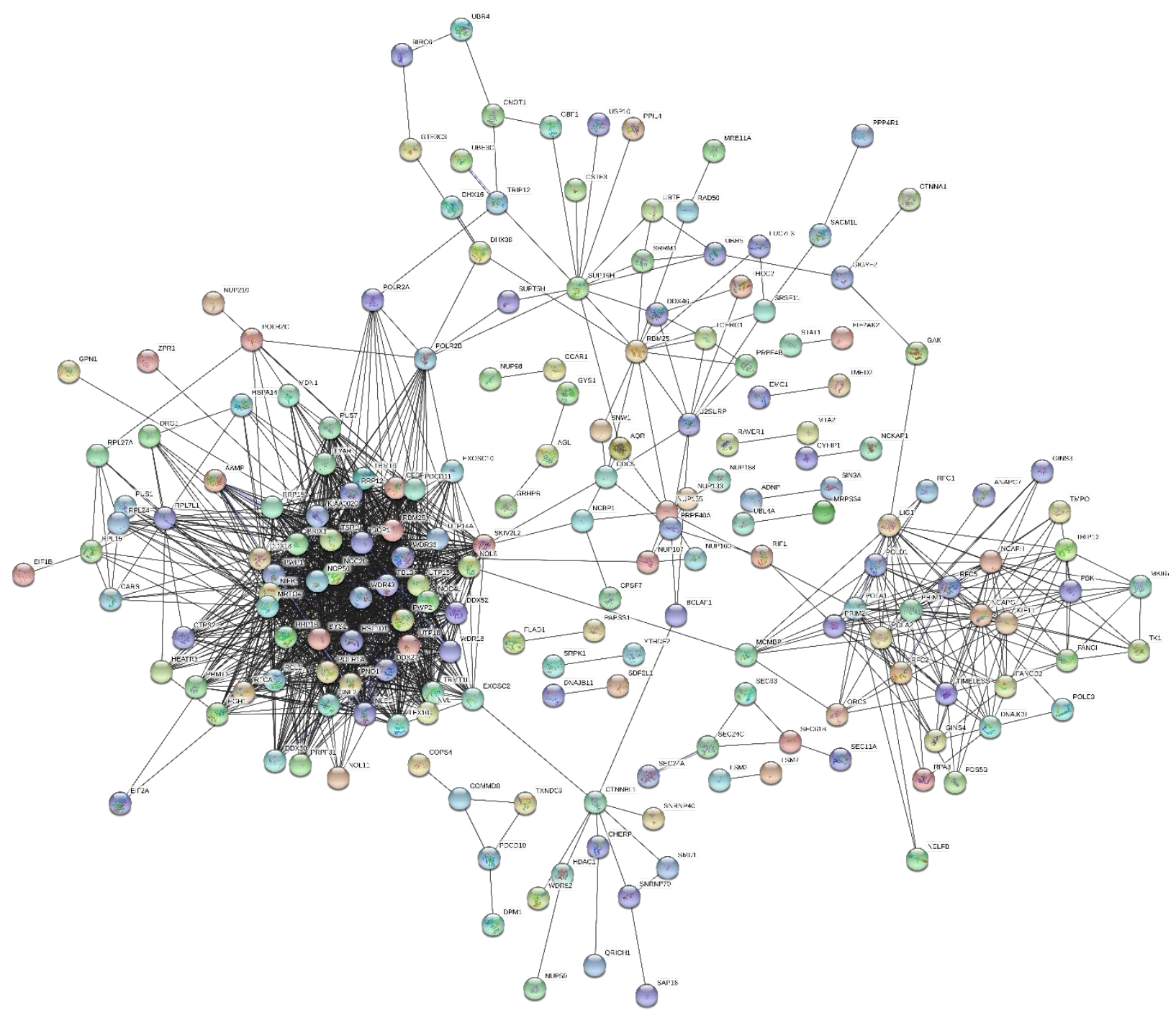

Figure S10. Protein co-expression network for nominated aptamer-binding partners generated with STRING v11. Shown are proteins with at least one co-expression interaction. Total number of nodes: 445 . Total number of coexpression interactions: 1381 (expected: 746, enrichment p-value: <1E-16). 


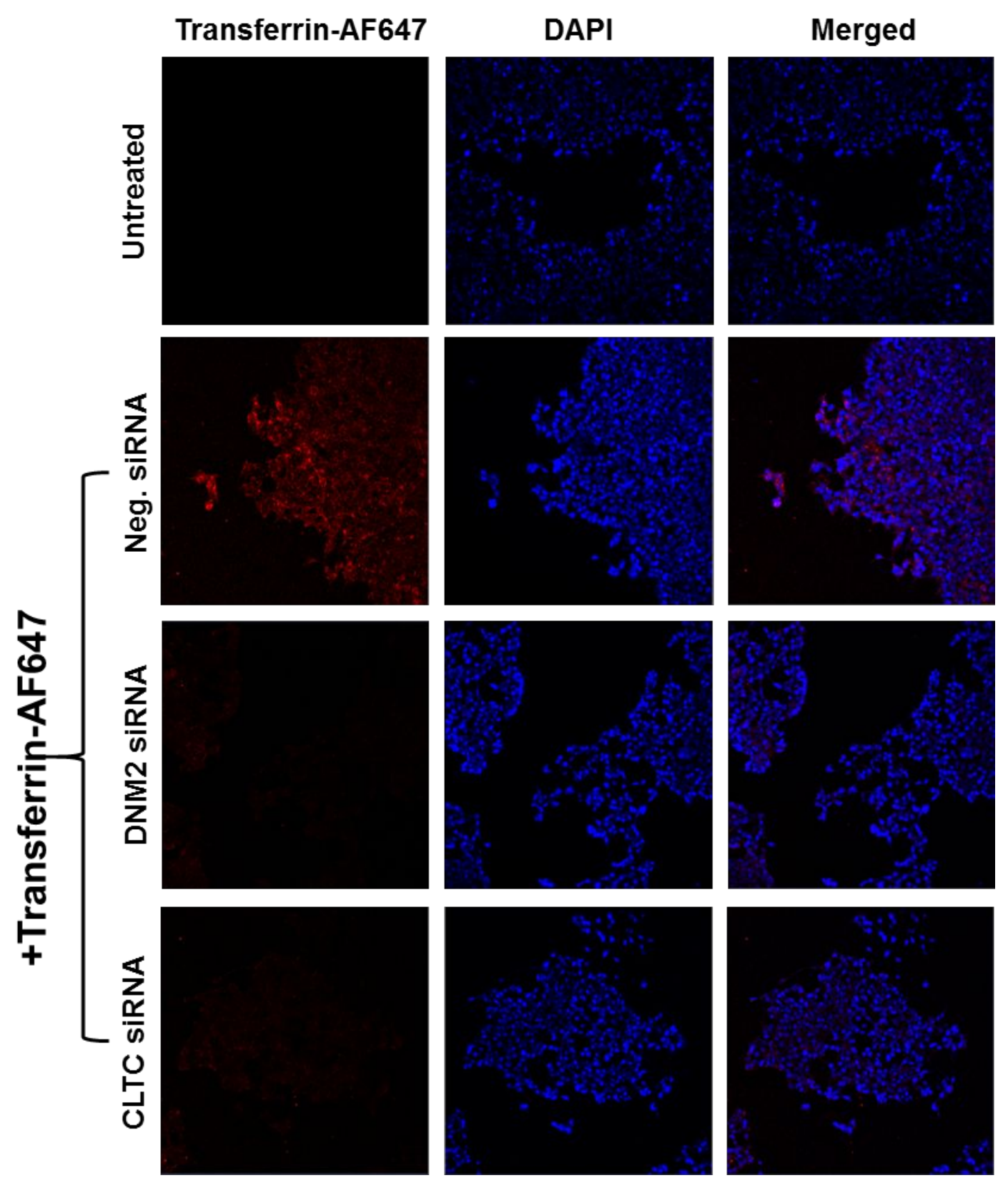

Figure S11. Confocal microscopy confirmation of siRNA knockdown of dynamin 2 (DNM2) and clathrin heavy chain (CLTC). Negative control siRNA had no impact on the uptake of Transferrin-AlexaFluor647 conjugates. 

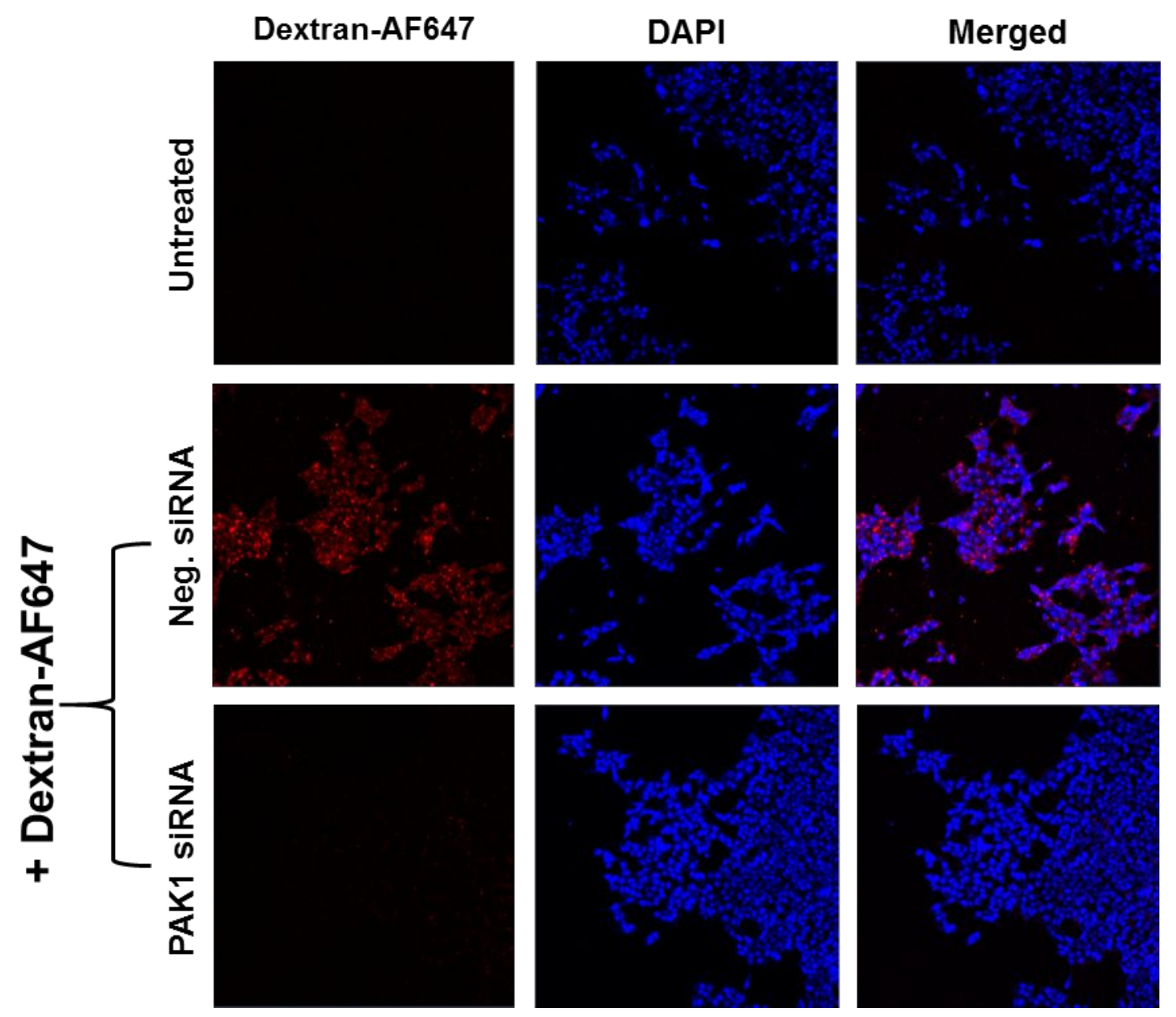

Figure S12. Confocal microscopy confirmation of siRNA knockdown of macropinocytosis (PAK1). Negative control siRNA had no impact on the uptake of Dextran-AlexaFluor647 conjugates. 


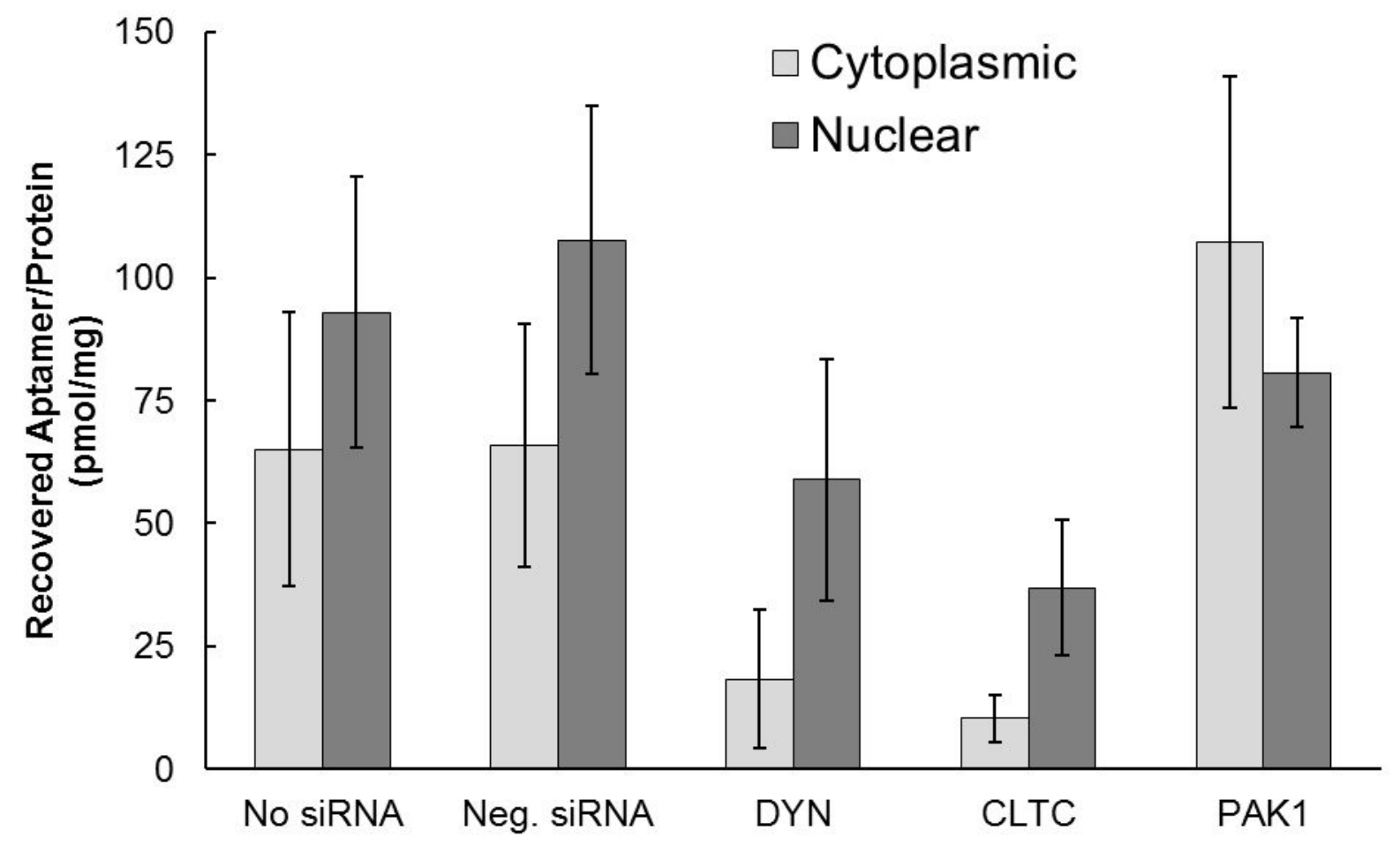

Figure S13. Elucidation of LJM-5588 endocytosis pathway. LJM-5588 uptake was not reduced by negative control siRNA or PAK1 siRNA treatment, but was decreased following treatment with DYN2 and CLTC siRNA. * p $<0.05$ vs. LJM-5588 cytoplasmic fraction. ** $\mathrm{p}<0.05$ vs. LJM-5588 nuclear fraction. 


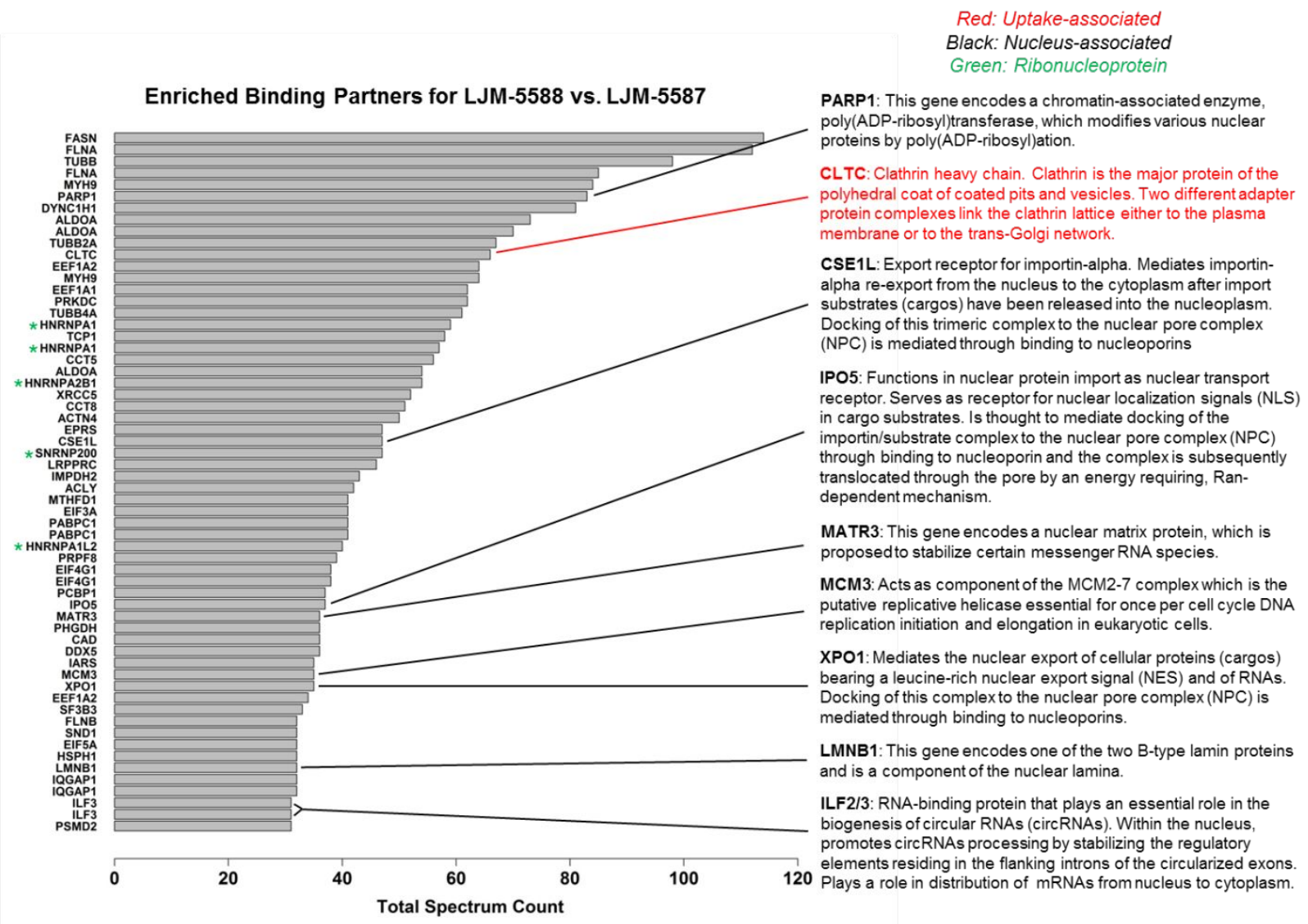

Figure S14. Identification of enriched binding partners for LJM-5588 sorted by total count. The top 60 enriched binding targets for LJM-5588, with notable examples of uptake-associated (red), nuclear (black), or ribonuclear proteins (green asterisk) highlighted. 


\subsection{Supporting Table}

\begin{tabular}{|c|c|c|c|}
\hline \multicolumn{4}{|c|}{ Clone 1 (LJM-5588) } \\
\hline \multirow[t]{20}{*}{ Base } & & rage $(\mathrm{N}=3)$ & DEV $(\mathrm{N}=3)$ \\
\hline & 83 & 0.153567496 & 0.104079185 \\
\hline & 80 & 0.221507306 & 0.069274908 \\
\hline & 73 & 0.108035689 & 0.051514203 \\
\hline & 69 & 0.129152312 & 0.049406727 \\
\hline & 66 & 1.523473781 & 0.227919056 \\
\hline & 58 & 0.07183197 & 0.056470683 \\
\hline & 57 & 0.042147195 & 0.025731466 \\
\hline & 53 & 1.248197531 & 0.76641559 \\
\hline & 51 & 0.961232111 & 0.314752401 \\
\hline & 47 & 1.360701727 & 0.460238251 \\
\hline & 44 & 0.680496695 & 0.277815089 \\
\hline & 39 & 0.140885321 & 0.051742308 \\
\hline & 34 & 1.036158379 & 0.204411477 \\
\hline & 31 & 1.429492356 & 0.378854925 \\
\hline & 28 & 1.77801296 & 0.470674865 \\
\hline & 26 & 1.589474521 & 0.335904963 \\
\hline & 23 & 1.097558597 & 0.261936129 \\
\hline & 17 & 1.452577963 & 0.128570704 \\
\hline & 14 & 0.849411853 & 0.052523167 \\
\hline
\end{tabular}

B Clone 2 (LJM-5589)

Base Average $(\mathrm{N}=3) \quad \operatorname{STDEV}(\mathrm{N}=3)$

$\begin{array}{lll}83 & 0.127632613 & 0.081967077\end{array}$

$81 \quad 0.739017163 \quad 0.221565713$

$77 ; 78 \quad 0.256323849 \quad 0.065074005$

$72 ; 73 \quad 0.122912325 \quad 0.048054482$

68;69 $\quad 1.045979605 \quad 0.158687526$

$\begin{array}{lll}66 & 2.330869127 & 0.076631638\end{array}$

$\begin{array}{lll}57 & 0.30369048 & 0.055552847\end{array}$

$\begin{array}{lll}49 & 0.463979747 & 0.013643691\end{array}$

$\begin{array}{lll}48 & 0.793402387 & 0.167267321\end{array}$

$\begin{array}{lll}46 & 0.604024551 & 0.112861559\end{array}$

$\begin{array}{lll}40 & 2.913244105 & 0.607923276\end{array}$

$\begin{array}{lll}38 & 1.791079154 & 0.226454384\end{array}$

$31 \quad 1.395796612 \quad 0.567459649$

$\begin{array}{lll}29 & 0.141239867 & 0.009162002\end{array}$

$\begin{array}{lll}26 & 0.766008941 & 0.131594318\end{array}$

$23 \quad 3.435360743 \quad 0.063446266$

$17 \quad 1.318185633 \quad 0.186091052$

$\begin{array}{lll}14 & 1.457493443 & 0.021944244\end{array}$

Table S1. Data from analysis of aptamer $\mathrm{KMnO}_{4}$ differential chemical reactivity under native and denatured conditions in support of Figure S6. Average values indicate ratios of chemical reactivity under native verses denatured conditions. 


\subsection{Supporting References}

1. Hoinka, J.; Backofen, R.; Przytycka, T. M., AptaSUITE: A Full-Featured Bioinformatics Framework for the Comprehensive Analysis of Aptamers from HT-SELEX Experiments. Mol Ther Nucleic Acids 2018, 11, 515-517.

2. $\quad$ Mergny, J. L.; Lacroix, L., Analysis of thermal melting curves. Oligonucleotides 2003, 13 (6), 515-37.

3. Kataoka, N.; Dreyfuss, G., A simple whole cell lysate system for in vitro splicing reveals a stepwise assembly of the exon-exon junction complex. J Biol Chem 2004, 279 (8), 7009-13.

4. $\quad$ Stoscheck, C. M., Quantitation of protein. Methods Enzymol 1990, 182, 50-68.

5. Raudvere, U.; Kolberg, L.; Kuzmin, I.; Arak, T.; Adler, P.; Peterson, H.; Vilo, J., g:Profiler: a web server for functional enrichment analysis and conversions of gene lists (2019 update). Nucleic Acids Res 2019, 47 (W1), W191W198.

6. Geiger, T.; Wehner, A.; Schaab, C.; Cox, J.; Mann, M., Comparative Proteomic Analysis of Eleven Common Cell Lines Reveals Ubiquitous but Varying Expression of Most Proteins. Mol Cell Proteomics 2012, 11 (3).

7. Szklarczyk, D.; Gable, A. L.; Lyon, D.; Junge, A.; Wyder, S.; Huerta-Cepas, J.; Simonovic, M.; Doncheva, N. T.; Morris, J. H.; Bork, P.; Jensen, L. J.; Mering, C., STRING v11: protein-protein association networks with increased coverage, supporting functional discovery in genome-wide experimental datasets. Nucleic Acids Res 2019, 47 (D1), D607-D613. 